\title{
Up-scaling potential impacts on water flows from agricultural water interventions: opportunities and trade-offs in the Osman Sagar catchment, Musi sub-basin, India
}

\author{
Kaushal K Garg ${ }^{1}$, Suhas P Wani ${ }^{1}$, Jennie Barron ${ }^{3,4}$, Louise Karlberg ${ }^{2,4}$, Johan Rockstrom ${ }^{2,4}$ \\ ${ }^{1}$ Resilient DryLand Systems, International Crops Research Institute for the Semi Arid Tropics (ICRISAT), \\ Patancheru 502 324, Andhra Pradesh India \\ ${ }^{2}$ Stockholm Environment Institute (SEI), Kräftriket 2B, 10691 Stockholm, Sweden \\ ${ }^{3}$ Stockholm Environment Institute, University of York, York YO10 5DD, United Kingdom \\ ${ }^{4}$ Stockholm Resilience Centre, Stockholm University, Kräftriket 2B, 10691 Stockholm, Sweden
}

\begin{abstract}
Agricultural water management (AWM) has been shown to improve and secure yields in the tropics and has been suggested as an important way to combat poverty in the region. In this paper we describe potential impacts on upstream and downstream flows of extensive AWM interventions, using the watershed development programme of the Osman Sagar catchment of Musi sub-basin, Andhra Pradesh semi-arid India, as an example. Various AWM interventions are compared with a non-intervention state and the current state of the study area, using 31years of data by application of the calibrated and validated ARCSWAT 2005 (Version 2.1.4a) modelling tool. Different AWM interventions contribute to improved livelihoods of upstream smallholder farmers by increasing soil moisture availability and groundwater recharge, which can subsequently be used for irrigation. The result is higher crop production and hence larger incomes. Moreover, lower flow intensities and sediment losses reduced by 30-50\%, reduce the risk of flooding and sediment accumulation in the Osman Sagar drinking water reservoir. On the other hand, AWM interventions are predicted to result in reduced total water inflows to the Osman Sagar reservoir from $11 \%$ of the total annual rainfall $(754 \mathrm{~mm})$ recorded at present, to $8 \%$ if AWM interventions were implemented at large scale throughout the catchment. A cost-benefit analysis of AWM interventions showed that the highest net economic returns were achieved at intermediate intervention levels (only in-situ AWM).
\end{abstract}

Keywords: SWAT, trade-offs, upstream-downstream, watershed development, Musi subbasin, Semi-arid India, Agricultural water interventions 


\section{Introduction}

Water is an increasingly scarce commodity in large parts of the world. Two principal users of water flows are agricultural systems, both rainfed and irrigated, and the ecosystem services that rely on quantity and quality of water for its functions. Rainfed agriculture in India plays a crucial role in ensuring food security but often coincides with a high incidence of poverty in local communities (Joshi et al., 2005). Yet, average crop yield in rainfed areas is below one ton $\mathrm{ha}^{-1}$, which is well below the potential achievable yield (Directorate of Economics and Statistics, Government of Andhra Pradesh, India, 2010; Singh et al. , 2009), and which is insufficient to feed the growing population and to generate income for local households. To improve crop yields it is essential both to meet national targets on food security as well as local household wellbeing and income goals. A number of research trials and simulation studies show that rainfed areas have the potential to produce crop yields several times higher than present levels (Wani et al. 2003, 2008; Rockström et al., 2007; Sahrawat et al. 2010) but low internal and external investment capacity, poor water and nutrient management and lack of knowledge are contributing factors that have kept rainfed areas consistently below the desirable production capacity over the past 50 years (Wani et al., 2003, 2008, 2011). About $60 \%$ of the total arable land (142 million ha) in India is rainfed, characterized by inadequate and erratic distribution of rainfall commonly resulting in water stress during critical stages of crop production.

Watershed development programs are considered to be an effective method for alleviating water stress in crop production systems and simultaneously augment groundwater recharge (Wani et al. 2008; Wani et al, 2011; Rockström et al., 2007, 2010; Rockström and Barron, 2007). Natural resource management at the watershed (catchment) or landscape scale ${ }^{1}$ not only increases food production, but can also have a number of social, economic and environmental co-benefits such as protection of the environment, increasing biodiversity and improving the livelihood status of local communities (Rockström et al. 2007). In India, several land and water management programs have been launched by the government with the help of various state departments, non-governmental organizations and research agencies, in which approximately US\$6 billion have been invested from the project inception phase (early 1980's) until 2006 (Wani et al., 2008).

\footnotetext{
${ }^{1}$ We here use the concept meso scale ranging from 1-10 $000 \mathrm{~km}^{2}$ for up-scaled analysis of aggregated landscape impacts on hydrology, yields and associated parameters of the study area.
} 
In the arid and semi-arid tropics where water is a key limiting factor to growth, competing inter-sectoral water demands (domestic, industrial and agricultural) are putting pressure on existing water resources (Biggs et al. 2007). In such situations, the implementation of watershed development programmes at the catchment scale may potentially cause undesirable impacts on downstream users, including ecosystem services, especially in terms of declining water flows. On the other hand, there are several positive consequences of watershed development programmes both at the upstream and downstream ends. Investments in land management increases green water use and improves crop productivity upstream, while at the same time prevents flooding, and soil and nutrient loss downstream (Rockström et al., 2007; Wani et al., 2003, 2011; Garg et al., 2011a), thus giving a positive impact to water quality (Sreedevi et al., 2006). In this paper the impacts of agricultural water management (AWM) interventions on water flows and sediment loss are studied in the Osman Sagar catchment, in the Musi subbasin of the Krishna basin in India. This catchment contains one of the drinking water reservoirs for the city of Hyderabad, India. After the introduction of watershed development programmes in the Osman Sagar catchment, inflows to the reservoir have decreased. As a consequence of this, in 1996, the Supreme Court of India took the decision not to extend any upstream development activities in the catchment area. A later study conducted by EPTRI, (2005) showed that the reduced inflows in Osman Sagar reservoir were mainly due to watershed development in upstream catchment areas. In a recent study, watershed interventions were shown to have significant impacts on water flows, sediment loss from the fields and crop yields in a small watershed of 465 ha (Garg et al., 2011a). However, none of the studies has looked thoroughly at various upstream-downstream impacts from watershed interventions in dry, normal and wet years on a longer time span, nor attempted to determine a value of the different upstream-downstream benefits and/or negative impacts associated with upstream developments.

In this paper we take a nested spatial-scale approach to assess impacts of different adoption scenarios of agricultural water interventions (AWM) included in watershed development programmes. In order to get the best possible benefits for all sections of society, a scientific approach is needed to assess the benefits and trade-offs of a particular approach to select the rational approach. The impact assessment focuses on catchment water partitioning changes, and changes in soil loss and river sediment loads. In addition, we look at potential impacts on income generation associated with the different agricultural water intervention scenarios as an indicator of potential poverty alleviation associated with interventions. The ultimate aim is to 
access the various principal trade-offs between spatially different users (upstream rural and downstream urban) as well as the potential benefits and/or adverse impacts of different AWM interventions as a regulating ecosystem service provider reducing sediments and threat of flooding thus enhancing supply of water to the downstream users.

The purpose is to understand the hydrology, soil and crop growth dynamics, using a hydrological modeling tool, the Soil and Water Assessment Tool (SWAT). More specifically, the study assesses the water partitioning and soil loss for four different agricultural water management intervention scenarios, and their impacts on: 1) crop production and income generation for people in upstream areas and 2) inflows of runoff water in to Osman Sagar reservoir providing drinking water supply for people in Hyderabad downstream.

\section{Site description}

The Osman Sagar catchment $\left(17.2-17.5^{\circ} \mathrm{N} ; 77.8-78.4^{\circ} \mathrm{E}\right)$ constitutes the upper part of the Musi sub-basin (Figure 1), and the total geographical area of the catchment is $736 \mathrm{~km}^{2}$ (EPTRI and NGRI, 2005). Most of the catchment is relatively flat with an elevation of 544 $688 \mathrm{~m}$ above sea level. The climate of the catchment is tropical monsoonal preceded by hot summers (minimum air temperature between 16 and $29{ }^{\circ} \mathrm{C}$ and maximum air temperature between 30 and $43{ }^{\circ} \mathrm{C}$ in May) and is followed by cool winters (minimum air temperature in between 6 and $20{ }^{\circ} \mathrm{C}$ and maximum air temperature between 23 and $32{ }^{\circ} \mathrm{C}$ in December), and an average annual rainfall of $800 \mathrm{~mm}$ (standard deviation, $\sigma=225 \mathrm{~mm}$ ). About $80-85 \%$ of the rainfall falls between June to October. However, the rainfall is highly erratic, both in terms of total amount and distribution over time.

The geology of the catchment is mainly dominated by hard rocks of Archaen granite and gneiss (Biggs et. al., 2008), and aquifers are either unconfined or perched, having poor storage capacity (specific yield=2.9 \%) (Massuel et al., 2007; Pavelic et al., 2012). Soils in the catchment range from shallow ( $<50 \mathrm{~cm}$ in $21 \%$ of catchment) to moderately deep (50 $100 \mathrm{~cm}$ in $18 \%$ of catchment) and deep (>100 cm, $61 \%$ of catchment), and are classified as Ustrorthents and Ustropepts, with limited Haplustalfs, Chromusterts, and Comborthids (Government of India, 1999; Reddy et al., 2005). Soil organic carbon content varies between 0.3 and $2.2 \%$, with an available water capacity of $0.12-0.19 \mathrm{~cm}^{3} \mathrm{~cm}^{-3}$ (Reddy et al., 2005). 
Cultivable land constitutes nearly $60 \%$ of the area in the catchment, while $20 \%$ is classified as wasteland (currently being used as pasture lands) and around $20 \%$ is domestic housing areas. Forests cover only $4 \%$ of the land (Table 1). Wastelands are degraded lands characterized by highly eroded, shallow soils, and are commonly used for grazing. Despite the large amount of land classified as cultivated land, more than half is lying fallow (Government of AP, India, 2007-2008). The reason for this is the proximity to the rapidly growing city of Hyderabad which has pushed up the price of land, with the result that former agricultural land is now being put on the market for housing development. In this transition phase, the land is left fallow. Most of the crops in the area are rainfed, and when irrigation is practiced, the water source is groundwater from open wells and tube wells. During the rainy (Kharif) season, sorghum, cotton, pulses, maize and paddy are the most common crops, while during the postrainy season (Rabi) chickpea, sorghum, wheat and vegetable crops are cultivated (Table 1). Yield data from 1991 - 2003 from the area shows that crop productivities per unit land area in the Osman Sagar catchment area are far below potential yields for similar hydro-climatic regions (Aggarwal et al., 2006, 2008; Bhatia et al., 2006; 2009).

Several watershed development programmes in the Osman Sagar catchment have been implemented since 1995 and onwards, including both in-situ (soil and moisture conservation) and ex-situ (water harvesting) practices [Census data, 2001, Government of Andhra Pradesh, India (unpublished)]. Water harvesting structures like check dams, percolation tanks, minipercolation tanks, gully control structures were built or restored in different micro-watersheds, creating a total storage capacity of $0.8-1.0 \mathrm{Mm}^{3}$ in the Osman Sagar catchment (equivalent to $10-15 \mathrm{~m}^{3} \mathrm{ha}^{-1}$ ) (The Hyderabad Metropolitan Water Supply and Sewerage Board, HMWSSB, 1995). A number of example studies, such as the one from the Kothapally watershed located in the catchment, show that such interventions have improved groundwater recharge, and crop yields while minimising soil loss (Wani et al., 2008; Pathak et al., 2002; Sahrawat et al., 2010; Garg et al., 2011a). Higher groundwater tables enabled supplementary irrigation with groundwater from open wells during the monsoon season, and resulted in a change in cropping pattern from rainfed sorghum to supplementary irrigated cotton, which is a relatively water demanding crop but at the same time has a high market value. Moreover, following the implementation of the watershed development programme in Kothapally, a fully irrigated vegetable crop is grown in the post-monsoon season, further contributing to improving farm incomes. However, the size of the cultivated area did not change in the watershed because of the agricultural water interventions. 
In 1920, the Osman Sagar reservoir was built across the Musi River with a storage capacity of $110 \mathrm{Mm}^{3}$. Hyderabad, the capital of Andhra Pradesh, is situated $20 \mathrm{~km}$ from the Osman Sagar reservoir, and the reservoir is one of the sources for supplying water for use to the city. On an average, $0.1 \mathrm{Mm}^{3}$ of water is supplied every day from the reservoir. This reservoir also has an important role in protecting Hyderabad city from flood during the monsoon period. Soil erosion poses land degradation issues upstream; and increases sediment loads in downstream water bodies (Yang et al., 2003). The Hyderabad Metropolitan Water Supply and Sewerage Board (HMWSSB, 1995) sixth annual report shows that capacity of the Osman Sagar reservoir was reduced by $12 \%$ of its total storage capacity between the years 1973 and 1988 because of sediment loading. This amount is equivalent to 15 ton soil ha $\mathrm{y}^{-1}$ erosion from the entire catchment area, and corresponds to the loss of approximately one centimeter of soil every decade from the catchment area.

\section{Methods}

\subsection{SWAT Parameterization procedure: data collection, calibration and validation}

The hydrological assessment of the Osman Sagar Catchment was conducted using the Soil and Water Assessment Tool (SWAT) (Arnold and Fohrer, 2005; Neitsch et al., 2005; Gassman et al., 2007). We used ArcSWAT2005, a public domain model (version 2.1.4a) in the present study. SWAT is one of the proven tools for hydrological studies at smaller watersheds (Kang et al., 2006; Green and Grienven, 2008; Garg et al., 2011a) to large river basins (Immerzal et al., 2008; Luo et al., 2008; Garg et al., 2011b) and continental scale (Schuol et al., 2008). A description of SWAT in the context of the present study has been reported in Garg et al. 2011a.

The model was first parameterized to represent the current land use and management situation based on observed data, data from the literature or simply assumed data based on model default values (Table 2a). Secondly, water flows and sedimentation processes were calibrated against observed values. Thereafter, the model was validated against water inflows into the Osman Sagar reservoir, water fluctuations in open wells in the area, yields for the monsoon crop and data collected at the Kothapally watershed. Simulations were conducted using a daily time-step from 1978 to 2008.

A $30 \mathrm{~m}$ spatial resolution digital elevation model (ASTER remote sensing data) was used to generate a drainage network for the Osman Sagar catchment area. Land-use practices were 
collected at the village level (Census of India, 2001; http://censusindia.gov.in/) (Table 1), and therefore village boundaries were superimposed on the stream network and outlets were selected in such a way that delineated micro-watersheds and village boundaries (political boundary) coincided, though exact matching was not possible. For cultivated areas, the major crops grown in the region (i.e. sorghum, cotton and pulses) were chosen to represent all crops in the present study (Table 1), using model default values. Parameters describing crop management operations like tillage, plantation, fertilization, irrigation (from groundwater) and harvesting were provided as input to the model. All crops received nitrogen and phosphorous before planting ( $\mathrm{N}$ and $\mathrm{P}$, each $50 \mathrm{~kg} \mathrm{ha}^{-1}$ ), and nitrogen once more as top dressing $(\mathrm{N}, 50 \mathrm{~kg}$ $\mathrm{ha}^{-1}$ ) during the cropping season as recommended. On irrigated lands, the monsoon crop was irrigated twice with $75 \mathrm{~mm}$ of water (each time). In addition, the post-monsoon crop on irrigated lands (i.e. chickpea) received $75 \mathrm{~mm}$ (each time) of irrigation water three times during the cropping season.

Soils in the catchment were broadly divided into 17 different classes (Reddy et al., 2005), and soil physical and chemical properties like soil hydraulic parameters, soil depth, texture details, and organic carbon were directly used as an input to the model as a function of depth (Reddy et al., 2005). This resulted in the entire catchment being divided into a total of 118 microwatersheds (or sub-basin in SWAT terminology) and further into 574 Hydrological Response Units (HRUs) based on land use and soil classes. HRUs are the basic computational units which aggregate spatially located areas of homogeneous land cover and soil type within a micro-watershed. Daily rainfall data from 10 rain gauge stations (Figure 1) located in each mandal (political unit comprises of several villages) was used in the simulations (data collected from the Indian Meteorological Department, Pune, India), together with daily data on maximum and minimum temperature, relative humidity, solar radiation, and wind speed from a nearby meteorological station (17.53 $\mathrm{N}$ and 78.27 E) at ICRISAT (Figure 1).

Data on the number of check dams, mini and large percolation tanks, farm ponds and other gully control structures built or regenerated across the watershed/villages and their years of construction under different watershed development schemes, were lumped together and a reservoir node was created in the model to represent current ex-situ interventions. This resulted in the generation of a total of 41 reservoir nodes of different storage capacities (1800 - $52000 \mathrm{~m}^{3}$ ) in the model (Figure 1), and the water in these reservoirs was allowed to recharge the groundwater aquifer. Table 1 shows cumulative gross storage capacity and 
surface area of check dams (ex-situ interventions) built in Osman Sagar catchment at current condition.

One reservoir node at outlet of the catchment boundary is created to represent the Osman Sagar reservoir in the model (Figure 1), and information on the total storage capacity and the surface area of the Osman Sagar reservoir was provided as inputs to the model (Table 2a). A total of $0.1 \mathrm{Mm}^{3}$ of water is withdrawn every day from the reservoir volume for drinking water supply to the city (HMWSSB, 2011).

The model was set-up for a period of 31 years (1978 to 2008) and calibrated against observed (1) inflows at Osman Sagar reservoir from 1978-1983 on annual time step and from 1984-94 on monthly time step, and (2) total sediment deposition in the Osman Sagar reservoir between 1978 and 1984. Thereafter, the model was validated against observed (1) monthly inflow data to the Osman Sagar reservoir between 1995 and 2004, (2) crop productivity (sorghum, cotton and chickpea) between 1999 and 2006; (3) water table fluctuations in open wells before and after the monsoon season between 1978 and 2002 (the relative change was compared to simulated groundwater fluctuations) (Table 2b). Moreover, model results were validated for a selected micro-watershed, Kothapally (Figure 1), where a large number of detailed measurements of surface runoff, groundwater recharge, crop yield and sediment loss were made between 2001 and 2010 (Garg et al., 2011a). Furthermore, model results were compared with other studies previously conducted in the same catchment or in the Musi sub-basin.

\subsection{Model Performance}

Simulated monthly inflows to the Osman Sagar reservoir correlated well with observed data for the calibration and validation period (Figure 2). The performance of the model was assessed based on the correlation coefficient (r), Nash-Suttcliffe efficiency (NSE) coefficient and the root mean square error (RMSE). The correlation coefficient was equal to 0.79 and 0.83 during the calibration and validation period, respectively. Since $\mathrm{r}$ values greater than 0.6 generally are considered "satisfactory" and values greater than 0.7 are considered as "good" (Chiew et al., 2002), the model performance was considered acceptable. Moreover, the RMSE of reservoir inflow was equal to 5.4 and $6.4 \mathrm{Mm}^{3}$ for the calibration and validation period, respectively. Positive values of NSE indicate that the calibrated model is a better predictor than the mean values of the observed discharge. The NSE coefficient for estimating inflow during calibration and validation is found to be 0.85 and 0.72 indicating good simulation 
capability, respectively. The model performance is found to be relatively better during the calibration period than the validation as shown by the scattered plot in Figure 2. Observed flow at Osman Sagar is found to be higher than the simulated values during the validation period especially during high rainfall events. This probably could be due to change in land use cover as more area under agricultural land is being converted into fallow or non-agricultural land over this period of time.

Simulated groundwater recharge and observed groundwater table fluctuations followed a similar pattern $(\mathrm{r}=0.84)$ (Figure 3). Because of different units, the variables are presented on different axes on the graph. Moreover, the specific yield calculated for the groundwater aquifer was comparable with other studies (Table $\mathbf{2 b}$ ). The amount of runoff leaving the Kothapally watershed boundary was found to be comparable with observed data (Table $\mathbf{2 b}$ ). Observed data on reservoir operation, spillover releases and evaporation/percolation losses indicated that this model was able to capture the reservoir hydrology very well (Table $2 \mathbf{b}$ ). Lastly, simulated crop yields for different crops are comparable with observed data and the RMSE of prediction is less than $20 \%$ of actual values (Table $\mathbf{2 b}$ ).

\subsection{Scenario development}

The entire simulation period between 1978 and 2008 is divided into three categories: dry, normal and wet years. According to the following classification (Indian Meteorological Department, Pune, India, http://www.imdpune.gov.in): rainfall less than $20 \%$ of the longterm average $=$ dry; rainfall between $-20 \%$ and $+20 \%$ of the long-term average $=$ normal; rainfall greater than $20 \%$ of long-term average $=$ wet. The total number of dry, normal, and wet years in the 31-year period were found to be 7, 16, and 8 times, respectively. Four scenarios of agricultural water management interventions were subsequently developed for the Osman Sagar Catchment, and based on the assumption that the practices implemented in the Kothapally watershed could be out-scaled to other locations in the catchment area. The scenarios are: 1) No Management condition (No Mgt.), 2) only In-situ (Insitu), 3) Only Exsitu (Exsitu) and 4) In-situ + Ex-situ (Max Int.). The first scenario (No Mgt.) thus represents a situation without any watershed programmes in place, while the last scenario (Max Int.) illustrates a full out-scaling of watershed programmes. The current situation of Osman Sagar lies between the No Mgt. and Max Int. scenarios in which SWAT setup is calibrated and validated. 
Scenarios that comprise in-situ practices (Insitu and Max Int.) were generated by assuming that the areas where in-situ interventions currently are in practice will remain the same, while the actual management is intensified. The parameterisation of soil characteristics for in-situ management was adopted from the Kothapally watershed case study (Garg et al., 2011a) (Table 2c). For scenarios comprising ex-situ practices (Ex-situ and Max Int.), structures were placed on the river network in the areas classified as cultivable land and wastelands at a density where the total storage capacity in the model scenario corresponds to that observed in the Kothapally watershed (Garg et al., 2011a). Thus, structures with a capacity of $40 \mathrm{~m}^{3} \mathrm{ha}^{-1}$ were constructed in the model setup over a total area of $552 \mathrm{~km}^{2}$ in the Osman Sagar catchment (Table 2c).

In the No Mgt. scenario, two short duration, drought tolerant crops, sorghum and chickpea, were assumed to be grown under rainfed conditions during the monsoon season (June to Oct) and the post-monsoon period (Nov-Feb), respectively, for the whole cultivated area except fallow lands (Table 2c). In the remaining three agricultural management scenarios (In-situ, Ex-situ and Max Int.), long duration cash crops like cotton replace sorghum during the monsoon and vegetable crops replace chickpea during post monsoon periods. The cotton crop was provided supplementary irrigations of $75 \mathrm{~mm}$ at each time of two critical crop growth stages. Full irrigation was supplied to the post-monsoon crop. Yield estimates were calculated using a post processing approach based on the availability of water for irrigation at the end of the monsoon season from the SWAT simulations. Availability of water was estimated from the groundwater level (SWAT output) during harvest of the monsoon crop and the lowest level of the wells. Thereafter, water is allocated towards annual domestic $(40 \mathrm{~L}$ day $^{-1}$ person $^{-1}$, rural areas) and livestock water needs $\left(30 \mathrm{~L}\right.$ day $^{-1}$ cattle $\left.^{-1}\right)$ (GOI; http://bharatnirman.gov.in/water1.html). Of the remaining amount of water, we assumed a $65 \%$ efficiency of groundwater use for irrigating the second crop (Jeevandas, et al., 2008). Water requirements per unit area were estimated under a "no water stress" situation for the second crop.

Gross incomes from the agricultural output were estimated from the market price of agricultural commodities (in this case the different crops) in 2006-07. Subsequently, net economic returns were calculated by subtracting the cost of cultivation (Government of Andhra Pradesh, India, 2007) from the gross income. The conversion rate for Indian rupees 
(15 May 2011) to US\$ was adopted as US $\$=45.81 ₹($ INR) in the present analysis. Income generated from livestock activities are not considered in the present analysis.

Economic trade-offs between water use at upstream and downstream locations was analyzed by comparing economic returns in the different water interventions scenarios. The amount of flow reduction to the Osman Sagar reservoir compared with the no intervention scenario is assumed to be compensated for by importing water from Nagarjuna Sagar reservoir which is located on the Krishna River. The cost of importing water from the Krishna River is higher

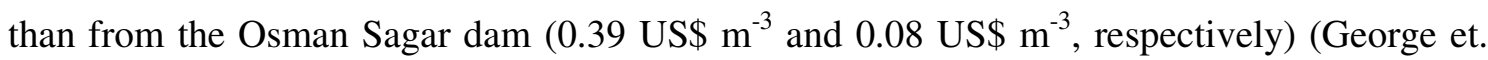
al., 2008). These costs were then related to the net economic returns from the farms, as described above.

\section{Results}

\subsection{Water balance components of different land management intervention scenarios}

The current water balance of the Osman Sagar catchment varies significantly between dry, normal and wet years (Figure 4). Evapotranspiration is the dominant water outflow, in particular during dry years, and varied between $45-85 \%$ of the total rainfall, although the absolute amount of evapotranspiration remains relatively constant between years at $385 \mathrm{~mm} \pm$ $36 \mathrm{~mm}$. Runoff and groundwater recharge both constitute between 5-25\% of the total water balance, ranging from $90 \mathrm{~mm} \mathrm{y}^{-1}$ to $140 \mathrm{~mm} \mathrm{y}^{-1}$ during dry years, respectively.

Scenarios of AWM interventions significantly (z-test, $\alpha=0.05$ ) changed the monsoonal water balance components (Figure 5). All combinations of AWM interventions resulted in higher evapotranspiration and lower runoff generation, and ex-situ conservation practices generated higher groundwater recharge during all seasons. For the No intervention stage (No Int.), approximately $57 \%(430 \mathrm{~mm} \pm 45 \mathrm{~mm})$ of the rainfall was partitioned into ET, whilst approximately $15 \%(112 \mathrm{~mm} \pm 60 \mathrm{~mm})$ was recharged to the groundwater aquifer and $13 \%$ (99 $\mathrm{mm} \pm 55 \mathrm{~mm}$ ) was generated as runoff from the catchment during the monsoon period in normal years. When the scenario of full watershed development programme was in place (Max Int.) the amount of water partitioned as ET had increased to around $480 \mathrm{~mm} \pm 55 \mathrm{~mm}$, equivalent to $64 \%$ of average monsoonal rainfall. Groundwater recharge was also higher (165 $\mathrm{mm} \pm 70 \mathrm{~mm}$ ) i.e., $22 \%$ of average monsoonal rainfall), while runoff from the watershed was less than $8 \%$ of the total water balance, i.e. $60 \mathrm{~mm}( \pm 45 \mathrm{~mm})$. 


\subsection{The Osman Sagar reservoir}

Between the years 1980-2001, the Osman Sagar reservoir received on average $62 \mathrm{Mm}^{3}$ of water during the monsoon period (Figure 6). On average, $30 \mathrm{Mm}^{3}$ water (48\%) was supplied to Hyderabad City for domestic water use, $20 \mathrm{Mm}^{3}$ (32\%) was lost through evaporation and $12 \mathrm{Mm}^{3}(19 \%)$ was spilled over to downstream river locations. Overflow of the dam to downstream locations occurred 11 times in 21 years during the period 1980-2001 when the reservoir reached its full storage capacity at the end of the monsoon period. The dam is expected to supply 35-40 $\mathrm{Mm}^{3}$ of water annually for Hyderabad domestic use (corresponding to $0.1 \mathrm{Mm}^{3}$ day $^{-1}$ ); however, in 7 out of 21 years, the water supply for domestic use from the dam was below $25 \mathrm{Mm}^{3}$ due to low inflows.

Different AWM interventions have the potential to significantly change downstream water availability at Osman Sagar reservoir (Figure 7). Inflows to the Osman Sagar reservoir varied from 10 to $25 \mathrm{Mm}^{3} \mathrm{y}^{-1}$ during dry seasons up to $90-130 \mathrm{Mm}^{3} \mathrm{y}^{-1}$ during wet seasons, under different land management scenarios, respectively. The largest reduction in flows resulted from ex-situ interventions (i.e. check-dams), although, in-situ interventions also reduced inflows to the dam. A full watershed implementation scenario (Max Int.) is predicted to reduce inflows to the dam by $30-60 \%$, compared with the hypothetical no intervention scenario (No Int.), depending on season. This corresponds to an absolute reduction of $35 \mathrm{~mm}$ or $25 \mathrm{Mm}^{3}$ per year. Reduction of runoff due to ex-situ intervention might be of importance in particular during wet years when the risk for flooding of downstream areas is higher (Figure 7). In wet years, inflows are predicted to reduce $30 \%$ (From $130 \mathrm{Mm}^{3}$ to $90 \mathrm{Mm}^{3}$ ) in Max Int. scenario and $11 \%$ under the current intervention stage $\left(130 \mathrm{Mm}^{3}\right.$ to $\left.115 \mathrm{Mm}^{3}\right)$ compared to No Int. scenario.

Reduced water inflows to the Osman Sagar reservoir are likely to impact the water supply to Hyderabad city and the release of water to the Musi river, located downstream. In case of inflow reduction, people in the city will have to be more dependent on other alternative water sources because the number of days of unmet water demand is found to increase. In normal years, the number of days per year with unmet demand for the no intervention scenario was estimated equal to 17 on average, while for the full watershed development programme scenario (Max Int.) the corresponding figure was 129 days (Figure 8). Moreover, the average spillover releases from the reservoir are predicted to be reduced from $11 \mathrm{Mm}^{3} \mathrm{y}^{-1}$ under the no 
intervention scenario, to $0 \mathrm{Mm}^{3} \mathrm{y}^{-1}$ (i.e. dry river conditions at downstream) with the full watershed development programme scenario (Max Int.) (Table 3).

Different AWM interventions are predicted to change the rate of sediment loading to the Osman Sagar reservoir (Figure 9). The average equivalent soil loss from the catchment is particularly high during wet seasons, and is estimated to vary by a factor of two with AWM interventions. During dry seasons the average soil loss was 2-5 tons ha $^{-1}$, while during wet seasons, it is $15-30$ tons ha $^{-1}$. Check-dams are predicted to reduce soil loss by up to $50 \%$ compared to no interventions. In-situ practices are also likely to reduce soil loss rates. The impact on the reservoir storage capacity is likely to be significant. Without any interventions (No Int.) the gross storage capacity of the dam is predicted to be reduced by $25 \%\left(27 \mathrm{Mm}^{3}\right)$ due to silt deposition in 31 years, compare to $11 \%\left(13 \mathrm{Mm}^{3}\right)$ under the watershed programme scenario with maximum interventions (Max Int.). The current state of the Osman Sagar catchment is closer to the scenario with no intervention (No Int.) and In-situ interventions (InSitu) than the scenario with maximum intervention (Max Int.)

\subsection{Upstream agricultural farming systems}

Water requirements in the Osman Sagar catchment for human and livestock needs were met from groundwater sources under each AWM scenario. However, in the present analysis we have not looked at groundwater availability on a spatial scale. Conclusions are drawn based on total groundwater availability in the entire catchment. Availability of groundwater for irrigating a second crop is found better under ex-situ interventions than in other AWM scenarios. Out of a total of $156 \mathrm{~km}^{2}$ of agricultural land, the potential groundwater availability without AWM interventions (No Int.) is estimated to be enough to cultivate $26 \mathrm{~km}^{2}$ of land during the (post-rainy) rabi season, which increases to $38 \mathrm{~km}^{2}$ under the implementation of Max Int. scenario, in dry years. The result is similar for normal and wet years (an increase of 10-20\%). However, since the present analysis assumes a maximum area of $156 \mathrm{~km}^{2}$ for cultivation, the irrigated area needs to be expanded through conversion of uncultivated fallow lands to cultivated lands (Table 1) during wet years for maximum utilization of the groundwater for cultivation in all management scenarios.

Crop yields of cotton during the rainy (Kharif) season are predicted to be highest under the Max Int. scenario, intermediate under the in-situ only scenario and lowest under the ex-situ only scenario (Table 3). Insitu interventions in cotton HRUs enhanced soil moisture levels, 
and reduced water stress situations led to increased crop yield. Comparisons with the No Int. scenario are not relevant in this case, since sorghum was grown in this scenario and not cotton.

Income generated from agricultural activities during both the rainy (Kharif) and post rainy (rabi) seasons is predicted to vary as a function of differences in yields, crop types and the respective market values in different AWM interventions (Figure 10). Net income is nearly doubled under the Max Int. scenario, compared to the No Int. scenario during dry years. The corresponding figure for normal and wet years is $50 \%$ and $30 \%$, respectively. Cost-benefit analysis of scenario yields revealed that income generation from the kharif season was higher than the rabi season during dry years, but lower during normal and wet years, but this finding is not only dependent on groundwater availability but also on crop choice and current market values. It was also found that the income from the rabi season crop was relatively more important for the ex-situ scenario compared to the in-situ scenario.

\subsection{Upstream-downstream trade-offs}

In relation to the no intervention (No Int.) scenario, all AWM interventions resulted in higher agricultural incomes, in particular during normal years (Figure 11a). On the other hand, costs to compensate for loss of drinking water supply to Hyderabad are highest during dry years, and in particular for the scenarios including ex-situ water interventions (Figure 11b). The net result is that, except in dry years, net economic returns are positive for all AWM scenarios (Figure 11c). In-situ practices were predicted to generate the highest economic returns, since these interventions resulted in enhanced agricultural incomes and a relatively small impact on downstream flows.

\section{Discussion}

\subsection{Water management interventions strengthen resilience to crop failure and improve income generation in upstream farming communities}

Efficient use of green water (e.g., infiltrated rainfall and soil moisture) can enhance crop productivity, income and provide better livelihood in rural areas. For instance in Kothapally, farmers shifted from low-value cereal grain crops (sorghum) to high-value and long duration crops (cotton) and vegetable crops because of availability of water in wells after AWM interventions (Sreedevi et al., 2004; Garg et al., 2011a). Water in open wells is found to be available till the end of the summer period during normal and wet years. Even during some 
dry years, water stored in the wells can be sufficient for irrigation although this depends on the amount of rainfall during the previous season.

Under the in-situ scenario, net economic returns were found to be consistently positive: upstream farmers' income increased, while at the same time sufficient water was available downstream for drinking water supply to Hyderabad. The situation may be referred to as a 'win-win' situation, with net benefits to several stakeholders. This analysis does not mean that flow reductions per unit area by in-situ interventions are smaller than for ex-situ interventions. In the present analysis, in-situ interventions were implemented only in $17 \%$ (i.e., agricultural land) of the total Osman Sagar catchment area. Implementing in-situ interventions on wastelands and fallow lands will only be useful if it is used for growing crop/trees,- or it may increase non-productive evaporation losses. On the other hand, the ex-situ scenario covered $74 \%$ of the total catchment area which includes agricultural lands, fallow lands and wastelands. Ex-situ interventions result in higher groundwater recharge, but higher groundwater levels may not benefit the area where it is implemented, for example, check dams constructed in wastelands are found to enhance groundwater recharge which benefits nearby agricultural areas.

An economic analysis accounting for direct provisional ecosystem services in terms of water yield to reservoir and crop yields to farmers show that various AWM interventions produced higher net economic returns compared to no interventions (No Int.) except in dry years. Historical rainfall data over the last 31 years showed that dry conditions occur once in four years. During those years there is in-sufficient drinking water generation under full-scale AWM interventions. There are other ecosystem services that have not been valued in this analysis, in particularly supporting and regulating services related to reducing peak flows and sediment loss which are shown to be affected by various AWM interventions. Reduction in peak flows and soil loss will remediate sediment loading in downstream water bodies. Osman Sagar reservoir already has a more than $12 \%$ reduction of its gross storage capacity due to excessive sedimentation between the years 1973 and 1988. Other non-valued aspects, which we did not account for in this benefit-cost analysis relate for example to the multiple benefits of improving productivity, income from livestock-based activities and livelihood of farmers in upland areas. These developments often also address poverty, equity and gender issues in watersheds. 
The current state of the Osman Sagar catchment is intermediate between the No Int. and Max Int. scenarios. The hydrological impacts of large scale implementation of AWM interventions are by no means insignificant. Several future development trajectories of the Osman Sagar could change this current state, for example i) higher water demands by Hyderabad City; ii) more development of in-situ and ex-situ agricultural water interventions upstream, and in a long term perspective iii) change in climatic conditions such as rainfall distribution and temperature increase (which may further enhance i) and ii)). All these highly feasible future outlooks will continue to put demands on water both upstream and downstream, making decisions on land and water resources in Osman Sagar a sensitive issue for policy and decision makers.

\subsection{Downstream water availability and inter-basin transfer}

Various water interventions in Osman Sagar catchment resulted in changed water balance partitioning, including increased evapotranspiration and shallow groundwater level, and decreased runoff and stream flows. In the present state, the Osman Sagar reservoir, which is one of the drinking water sources of Hyderabad city, contributes on average $11 \%$ of the total domestic water needs of the city. Currently, the total annual water demand is $320 \mathrm{Mm}^{3}$ (George et al., 2008), but the demand for water is consistently increasing with increasing population and economic growth. It is anticipated that approximately $600-700 \mathrm{Mm}^{3}$ and $800-$ $1000 \mathrm{Mm}^{3}$ water will be required for Hyderabad city in year 2020 and 2030, respectively (George et al., 2008.). There are other alternative water sources recognized located in the Krishna basin (Nagarjuna Sagar) and the Godavari basin (Singur and Manjeera dam) to meet water demands, however, importing water from other sources is expensive. Capacity and willingness to pay for good quality water in urban areas is higher than in rural areas. Intensifying AWM interventions in the Osman Sagar catchment will affect downstream water availability and drinking water supply from the reservoir, but the impact on the total water supply in relation to gross water demand is less significant. However, there is always a break point, where upstream AWM interventions also reduce sediment flows, and thus have a positive impact, easily valued in terms of longer reservoir lifespan and also reduced land degradation in upstream areas.

It should also be made clear that the economic benefits and costs generated by water are not necessarily distributed equitably. Upstream gains due to increase crop yields will benefit poor 
individual households as upland rainfed areas are the hotspots of poverty, whereas the Osman Sagar reservoir ultimately benefits the urban supply system of water which is a parastatal.

\subsection{Comparison of results with other studies}

To understand the hydrological impacts of the water harvesting (e.g., AWM) structures in the Upper Musi sub-basin (Osman Sagar and Himayat Sagar catchments), the Environmental Protection Training and Research Institute (EPTRI) together with National Geophysical Research Institute (NGRI), Hyderabad, conducted a hydrological study using a groundwater flow model (MODFLOW). This model was set-up for a two year period and an analysis was made for current management practices and no management conditions. Groundwater recharge in the Osman Sager catchment area and the inflow to the Osman Sagar reservoir estimated by EPTRI and NGRI was comparable with the present study (Table 2b) but discrepancy is found for No Mgt/No Int. scenarios. Rainfall data showed that year 2004-05 was an extreme dry year (rainfall $=595 \mathrm{~mm}$ or $440 \mathrm{Mm}^{3}$ ) however EPTRI- NGRI, (2005) predicted Osman Sagar inflow as $102 \mathrm{Mm}^{3}$ whereas present analysis merely predicted inflow amount $20 \mathrm{Mm}^{3}$ for No Mgt/No Int. condition. The EPTRI -NGRI study (2005) assumed that year 2004-05 could have received similar inflow as was recorded in year 1970 under no management interventions. Year 1970 was a wet year $\left(\right.$ Rainfall $=1124 \mathrm{~mm}$ or $825 \mathrm{Mm}^{3}$ ); anticipating similar inflow at Osman Sagar reservoir for the no management condition in a dry year (in 2004-05) probably was an exaggeration on flow reduction due to watershed interventions. We described the difference in reservoir inflow between No Mgt and Max Int. as $40 \mathrm{Mm}^{3}\left(130-90 \mathrm{Mm}^{3}\right)$ during wet years and $13 \mathrm{Mm}^{3}\left(28-15 \mathrm{Mm}^{3}\right)$ during dry years.

A study of water harvesting in tropical climates (Rajasthan, India) showed that ex-situ interventions increase sustainability of water resources for irrigated agriculture compared to no water interventions (Glendenning and Vervoort, 2011). Water harvesting structures provided a slight buffer in the groundwater storage when drought occurs. Similar observations have been made for parts of the Osman Sagar catchment (Garg et al., 2011a) and are confirmed in the present study. Moreover, Glendenning and Vervoort, 2011 showed that above a critical limit, building more structures only reduces water flows at downstream locations, and does not contribute to additional groundwater recharge.

Recently, Bouma et al. (2011) studied upstream-downstream trade-offs of the Upper Musi sub-basin, which includes three dams: Osman Sagar and Himayat Sagar catchments as 
upstream locations, and Nagarjurna Sagar as a downstream location. The study of Bouma et al. (2011) concluded that capital invested under various water interventions in the Upper Musi sub-basin are not remunerative and therefore recommended to develop various infrastructures (roads, schools, hospitals etc.) rather than investing more money in watershed development programs. They focused only on economic returns obtained out of the total capital invested in watershed program and grossly overlooked/ neglected the equity concerns of addressing the issue of poverty reduction for upland people through watershed management. Despite this, the results presented here show that accounting for the improvements in yield with AWM and the lower ability of the Osman Sagar dam to supply water for meet drinking water demands under varying climatic conditions, we obtained a net benefit with AWM compared to without. We ascribe the differences in result to the use of an improved modeling approach which better represents both water and sediment flows, as well as crop yields, under varying climatic conditions (dry, normal, wet years). If our analysis were to include various social and environmental gains/benefits as described in previous meta-analyses of watershed programs in India (Joshi et al., 2008), the outcome of this analysis may differ. However, as Joshi et al (2008) conclude, there are a range of social and environmental benefits that also need to be addressed and valued for obtaining a strong case in water allocation between different users and uses in catchments and basins under watershed interventions

\subsection{Uncertainties in the analysis}

Several assumptions made in the scenario development are important to address. Mono cropping patterns are assumed in the analysis; however, there are several crop combinations possible and their market price is very sensitive to net economic returns. To address this, the simulated crop yields from the ARCSWAT would need to be linked with a trade model, which was beyond the scope of this study. Such coupling of hydrological impacts, crop yields and implications on market prices is being developed at continental scale through combining SWAT and DREAM ${ }^{2}$ by IFPRI. A second assumption was made regarding irrigated areas being limited to a maximum agricultural land area in the Rabi season despite the fact that a large fraction of fallow land remains uncultivated (modeled as waste land). Thirdly, this analysis does not account for increasingly smaller reservoir storage capacity of the Osman Sagar reservoir, neither for up-stream ex-situ storage structures, because of siltation build-up.

\footnotetext{
${ }^{2}$ This development is undertaken for the AgWAter Solutions project and the results have not yet been published. The scale of the linking is at continental scale currently applied for Africa.
} 
This may not be a concern at upstream locations as local communities tend to empty ex-situ structures. However, for the Osman Sagar reservoir this effect actually induces a reduced lifespan of the reservoir, and thus has potential net impacts on the benefit-cost analysis. We speculate that including the reduction of lifespan would increase the benefit (return) of implementing agricultural water interventions further.

\section{Conclusion}

The watershed development program is identified as an adaptation strategy for increasing agricultural production and income under present and future climatic situations of arid and semi-arid tropics. There is a need to understand various trade-offs between upstream and downstream locations. In this study, the hydrological processes of different AWM interventions were modelled for the Osman Sagar catchment of the Musi sub-basin using the distributed hydrologic model, SWAT. The key findings of this study are:

- Different AWM interventions significantly changed the water balance components in the catchment. Full-scale implementation of AWM interventions compared with a no intervention scenario resulted in higher groundwater recharge from 15 to $22 \%$ of total rainfall, higher evapotranspiration (57 to $64 \%$ of total rainfall) and lower inflow to the downstream water reservoir (13 to $8 \%$ of total rainfall).

- Higher soil moisture and groundwater availability predicted for different AWM interventions scenarios can generate higher crop yields and subsequently higher farm incomes at upstream locations. At the same time, reduced flow intensity and sediment accumulation in downstream water bodies increases system resilience against external shocks like drought and flood events.

- AWM interventions reduce inflows to the Osman Sagar reservoir, especially during dry years. However the reduced inflow due to AWM interventions at the Osman Sagar reservoir is less than five per cent of the total water demand of the Hyderabad city.

- Net economic returns except during dry years are positive for all water management interventions scenarios. In-situ practices were predicted to generate the highest economic returns, since these interventions resulted in enhanced agricultural incomes and a relatively small impact on downstream flows.

- The results are sensitive to parameter selection and model assumptions, adopted methodology and also the selected scale of assessment. We did not value the poverty alleviation, environmental flow, sediment and nutrient transport and other ecosystem 
services or social benefits such as equity, poverty reduction and gender in the current study. Future developments, in water-demand downstream, climate change and/or agricultural development upstream, may shift the precarious state of net benefits accounted for here. Including various non-economically social and environmental impacts associated with urban downstream or rural upstream developments will likely further shift overall net return analysis.

\section{Acknowledgement}

The authors are thankful to Mr. Sanjay Gupta, IFS, Command Area Development Authority, Hyderabad for providing Osman Sagar inflow data on a monthly time scale. This work was funded through the SIDA grant to support Stockholm Resilience Centre research collaborations in India. Additional funding for Jennie Barron was supported by FORMAS Exec. Financial support to ICRISAT from the Asian Development Bank (ADB), Manila Philippines through RETA 5812 and RETA 6067 enabled development of Kothapally watershed is also gratefully acknowledged.

\section{References}

Aggarwal PK, Banerjee B, Daryaei MG, Bhatia A, Bala A, Rani S, Chander S, Pathak H and Kalra N (2006) InfoCrop: A dynamic simulation model for the assessment of crop yields, losses due to pests and environmental impact of agro-ecosystems in tropical environments II Model performance. Agric Systems, 89: 47-67.

Aggarwal PK, Hebbar KB, Venugopalan MV, Rani S, Bala A, Biswal A and Wani SP (2008) Quantification of Yield Gaps in Rain-fed Rice, Wheat, Cotton and Mustard in India. Global Theme on Agroecosystems Report no. 43. Patancheru 502 324, Andhra Pradesh, India: International Crops Research Institute for the Semi-Arid Tropics. 36 pages.

Ahmed S and Sreedevi PD. 2008. Simulation of flow in weathered-fractured aquifer in a Semi-Arid and over-exploited region. In Groundwater dynamics in hard rock aquifers, Ahmed S, Jayakumar R, Salih A (eds), Springer Publication.

Arnold, JG and Fohrer N (2005) SWAT2000: current capabilities and research opportunities in applied watershed modeling. Hydrological Processes, 19: 563-572.

Bhatia VS, Singh P, Wani SP, Rao AVK and Srinivas K (2006) Yield gap analysis of soybean, groundnut, pigeonpea and chickpea in India using simulation modeling. Global Theme on Agroecosystems, Report No. 31, Patancheru 502 324. Andhra 
Pradesh, India: International Crops Research Institute for the Semi-Arid Tropics. 156 pp.

Bhatia VS, Singh P, Rao AVRK, Srinivas K, Wani SP (2009) Analysis of Water Non-limiting and Water Limiting Yields and Yield Gaps of Groundnut in India Using CROPGROPeanut Model. J. Agronomy \& Crop Science, 195 (6):455-463.

Biggs TW, Mishra PK and Turral H (2008) Evapotranspiration and regional probabilities of soil moisture stress in rainfed crops, southern India. Agricultural and Forest Meteorology, 148 (11): 1585-1597.

Biggs T, Gaur A, Scott C, Thenkabail P, Gangadhara Rao P, Gumma MK, Acharya S and Turral H (2007) Closing of the Krishna Basin: irrigation, streamflow depletion and macroscale hydrology. Colombo, Sri Lanka: International Water Management Institute (IWMI). 38p. (IWMI Research Report 111).

Bouma JA, Biggs TW and Bouwer LM (2011) The downstream externalities of harvesting rainwater in semi-arid watersheds: An Indian case study. Agricultural Water Management (In press/online).

Chiew FHS, Peel MC and Western AW (2002) Application and testing of the simple rainfallrunoff model SIMHYD. In Mathematical Models of Small Watershed Hydrology and Applications, Singh VP, Frevert DK (eds). Water Resources Publications: Littleton, Colo.; 335-367.

Directorate of Economics and Statistics, Government of Andhra Pradesh, India (2010). Hand book of statistics. http://www.apdes.ap.gov.in/publications/

Environment Protection Training \& Research Institute (EPTRI) and National Geophysical Research Institute (NGRI) Hyderabad, September (2005) Ecology of Himayath Sagar and Osman Sagar lakes - Evaluation of permissible developmental activities in the catchment areas. Report submitted to Municipal Administration \& Urban Development Department, Government of Andhra Pradesh.

Garg KK, Karlberg L, Barron J, Wani SP and Rockström J (2011a) Assessing impact of agricultural water interventions at the Kothapally watershed, Southern India, Hydrological Processes 26(3): 387-404.

Garg, KK, Bharati L, Gaur L, George B, Acharya S, Jella K and Narasimhan B (2011b). Spatial Mapping of Agricultural Water Productivity using SWAT model in Upper Bhima Catchment, India. Irrigation and Drainage DOI: 10.1002/ird.618. 
Gassman PW, Reyes MR, Green CH and Arnold JG (2007) The Soil and Water Assessment Tool: Historical development, application and future research directions. Transactions of the ASABE, 50(4): 1211-1250.

George BA, Malano HM, Khan AR, Gaur A and Davidson B (2008) Urban Water Supply Strategies for Hyderabad, India - Future Scenarios. Environmental Modeling Assessment, 14(6): 691-704..

Glendenning CJ and Vervoort RW (2011) Hydrological impacts of rainwater harvesting (RWH) in a case study catchment: The Arvari River, Rajasthan, India. Part2. Catchment -scale impacts. Agricultural Water Management, 98: 715-730.

Government of Andhra Pradesh, India (2007-2008) Hand book of statistics Ranga Reddy District 2007-2008. Published by Chief Planning officer Ranga Reddy District, Hyderabad, India.

Govt. of India, Ministry of water resources (1984) Groundwater Estimation Methodology Central Groundwater Board, 1975. Hydrogeology of 56G (East) 56 K (West) India Tech Report Canadian Assisted Groundwater Project.

Government of India (1999) Soil Map of Andhra Pradesh. National Bureau of Soil Survey and Land Use Planning (ICAR), Bangalore.

Green CH and van Griensven A (2008) Autocalibration in hydrologic modeling: Using SWAT2005 in small-scale watersheds. Environmental Modelling and Software, 23(4): 422-434. Doi: 10.1016/j.envsoft.2007.06.002.

HMWSSB (1995) Hyderabad Metropolitan Water Supply and Sewerage Board, Sixth annual report, 1994-1995, Hyderabad

HMWSSB (2011) Hyderabad Metropolitan Water Supply and Sewerage Board, http://www.hyderabadwater.gov.in/wwo/UI/sourceandstorage.aspx

Immerzeel WW, Gaur A and Zwart SJ (2008) Integrating remote sensing and a process-based hydrological model to evaluate water use and productivity in a south Indian catchment. Agricultural Water Management, 95: 11-24.

Jeevandas A, Singh RP and Kumar R (2008) Concerns of Groundwater Depletion and Irrigation Efficiency in Punjab Agriculture: A Micro-Level Study. Agricultural Economics Research Review, 21: 191-199.

Joshi PK, Jha AK, Wani SP, Joshi L and Shiyani RL (2005) Meta-analysis to assess impact of watershed programme and people's participation. Research report no. 8. International 
Crops Research Institute for the Semi Arid Tropics, Patancheru, India and Asian Development Bank, Manila, the Philippines.

Joshi PK, Jha AK, Wani SP, Sreedevi TK and Shaheen FA (2008) Impact of watershed program and conditions for success: A meta-analysis approach. Global Theme on Agroecosystems Report no. 46. Patancheru 502 324, Andhra Pradesh, India; International Crops Research Institute for the Semi-Arid Tropics. 24 pp.

Kang MS, Park SW, Lee JJ and Yoo KH (2006) Applying SWAT for TMDL programs to a small watershed containing rice paddy fields. Agricultural Water Management, 79(1): $72-92$.

Luo Y, He C, Sophocleous M, Yin Z, Hongrui R and Ouyang Z (2008) Assessment of crop growth and soil water modules in SWAT2000 using extensive field experiment data in an irrigation district of the Yellow River Basin. Journal of Hydrology, 352: 139 -156.

Massuel S, George BA, Gaur A and Nune R (2007) Groundwater modelling for sustainable water resources management in the Musi Catchment, India. MODSIM-2007, Christchurch, Dec 10-14, 2007.

Neitsch SL, Arnold JG, Kiniry JR, Williams JR and King KW (2005) Soil and Water Assessment Tool. Theoretical documentation, Version 2005.

Pathak P, Wani SP, Singh P, Sudi R and Rao CS (2002) Hydrological characterization of benchmark agricultural watershed in India, Thailand, and Vietnam. Global Theme on Agroecosystems Report No. 2. Andhra Pradesh, India: International Crops Research Institute for the Semi-Arid Tropics.

Pavelic P, Patankar U, Acharya S, Jella K, Gumma MK (2012). Role of groundwater in buffering irrigation production against climate variability at the basin scale in SouthWest India. Agricultural Water Management 103:78- 87.

Reddy RS, Budihal SL, Kumar SCR and Naidu LGK (2005) Benchmark soils of Andhra Pradesh. NBSS Publ. No. 128, NBSS\&LUP, Nagpur, pp143.

Rockström J and Barron J (2007) Water Productivity in Rainfed Systems: Overview of challenges and analysis of opportunities in water scarcity prone savannahs. Irrigation Science, 25:299-311

Rockström J, Hatibu N, Oweis T, Wani SP, Barron J, Bruggeman A, Qiang Z, Farahani J and Karlberg, L (2007) Managing Water in Rainfed Agriculture. In. Molden D. (editor) Water for Food, Water for Life: A Comprehensive Assessment of Water Management in Agriculture. Chapter 9: 315-348. Earthscan, London. 
Rockström J, Karlberg L, Wani SP, Barron J, Hatibu N, Oweis T, Bruggeman A, Farahani J and Qiang Z (2010) Managing water in rainfed agriculture: the need for a paradigm shift. Agricultural Water Management, 97(4): 543-550

Sahrawat KL, Wani SP, Pathak P and Rego TJ (2010) Managing natural resources of watersheds in the semi-arid tropics for improved soil and water quality: A review. Agricultural Water Management, 97: 375-381.

Schaap MG, Leij FJ, van Genuchten M Th. 2001. Rosetta: a computer program for estimating soil hydraulic parameters with hierarchical pedotransfer functions. Journal of Hydrology 251: 163-176.

Schuol J, Abbaspour KC, Srinivasan R and Yang H (2008) Estimation of freshwater availability in the West African sub-continent using the SWAT hydrologic model. $J$. Hydrol., 352, 30-49.

Singh P, Aggarwal PK, Bhatia VS, Murty MVR, Pala M, Oweis T, Benli B, Rao KPC and Wani SP (2009) Yield gap analysis: Modelling achievable yields at farm level, In' ainfed Agriculture: Unlocking the potential' Eds S.P. Wani, J. Rockstrom, T. Oweis, Comprehensive Assessment of Water Management in Agriculture Series No7, ,IWMI, ICRISAT, Cab International p 81-123

Sreedevi TK, Shiferaw B and Wani, SP (2004) Adarsha Watershed in Kothapally, Understanding the drivers of higher impact. Global Theme on Agroecosystems Report No. 10. Andhra Pradesh, India: International Crops Research Institute for the SemiArid Tropics.

Sreedevi TK, Wani SP, Sudi R, Patel MS, Jayesh T, Singh SN and Shah T (2006) On-site and Off-site Impact of Watershed Development: A Case Study of Rajasamadhiyala, Gujarat, India. Global Theme on Agroecosystems Report No. 20, Patancheru 502 324, Andhra Pradesh, India: International Crops Research Institute for the Semi-Arid Tropics. 48 pp.

Wani SP, Pathak P, Sreedevi TK, Singh HP, Singh P (2003) Efficient management of rainwater for increased crop productivity and groundwater recharge in Asia. In Water productivity in agriculture: limits and opportunities for improvement, ed. Kijne JW, Barker R, Molden D, 199-215. Wallingford, UK: CAB International; and Colombo, Sri Lanka: International Water Management Institute (IWMI).

Wani SP, Joshi PK, Raju KV, Sreedevi TK, Wilson MJ, Shah A, Diwakar PG, Palanisami S, Marimuthu S, Jha AK, Ramakrishna YS, Sundaram MSS and D'Souza M (2008) Community watershed as a growth engine for development of dryland areas. A 
comprehensive assessment of watershed programs in India. Global Theme on Agroecosystems Report No. 47. Andhra Pradesh, India: International Crops Research Institute for the Semi-Arid Tropics.

Wani SP, Anantha KH, Sreedevi TK, Sudi R, Singh SN and D'Souza M (2011) Assessing the Environmental Benefits of Watershed Development : Evidence from the Indian SemiArid Tropics. Journal of Sustainable Watershed Science \& Management, 1(1):10-20

Yang D, Kanae S, Oki T, Koike T and Musiake K (2003) Global potential soil erosion with reference to land use and climate changes. Hydrological Processes, 17 (14): 29132928. 


\section{List of Tables}

Table 1: Land use classification and land management inputs

\begin{tabular}{|c|c|c|c|c|c|c|c|c|c|c|c|c|c|c|c|}
\hline \multirow{2}{*}{\multicolumn{2}{|c|}{$\begin{array}{l}\text { Land Use classes in } \\
\text { the Osman Sagar } \\
\text { catchment }\end{array}$}} & \multirow{2}{*}{$\begin{array}{l}\text { Land Use } \\
\text { (modeled) }\end{array}$} & \multirow{2}{*}{$\begin{array}{l}\text { Area } \\
(\%)\end{array}$} & \multicolumn{12}{|c|}{ Crop growing period } \\
\hline & & & & $\mathbf{J}$ & $\mathbf{J}$ & $\overline{\mathbf{A}}$ & $\mathbf{S}$ & $\mathbf{O}$ & $\mathbf{N}$ & $\mathbf{D}$ & $\mathbf{J}$ & $\mathbf{F}$ & $\mathbf{M}$ & $\mathbf{A}$ & $\mathbf{M}$ \\
\hline \multicolumn{2}{|l|}{ Forest land } & Forest & 4 & & & & & & & & & & & & \\
\hline \multirow{5}{*}{$\begin{array}{l}\text { Cultivable } \\
\text { land }\end{array}$} & \multirow[t]{3}{*}{ Rainfed } & Sorghum & 11 & & & & & & & & & & & & \\
\hline & & Cotton & 4 & & & & & & & & & & & & \\
\hline & & Fallow land* & 35 & & & & & & & & & & & & \\
\hline & \multirow[t]{2}{*}{ Irrigated } & Sorghum & 1.7 & & & & & & & & & & & & \\
\hline & & Sorghum-chickpea & 4.5 & & & & & & & & & & & & \\
\hline \multicolumn{2}{|l|}{ Wasteland } & Wasteland & 18.8 & & & & & & & & & & & & \\
\hline \multicolumn{2}{|c|}{ Non Agric. use } & Settlements-rural & 20 & & & & & & & & & & & & \\
\hline \multicolumn{2}{|l|}{ Water body } & Water body & 1 & & & & & & & & & & & & \\
\hline
\end{tabular}

*Modelled as wasteland. 
Table 2a Model parameterisation

\begin{tabular}{|c|c|c|c|}
\hline Variable (unit) & $\begin{array}{l}\text { Name in } \\
\text { SWAT }\end{array}$ & Value & Source \\
\hline Sand content $(\%)$ & SAND & $35(5-83)^{*}$ & Reddy et al., 2005 \\
\hline Silt content (\%) & SILT & $23(5-59)$ & Reddy et al., 2005 \\
\hline Clay content $(\%)$ & CLAY & $42(3-61)$ & Reddy et al., 2005 \\
\hline Gravel fraction $(\%)$ & ROCK & $7(5-13)$ & Reddy et al., 2005 \\
\hline Bulk Density $\left(\mathrm{g} \mathrm{cm}^{-3}\right)$ & SOL_BD & $1.45(1.2-1.6)$ & Reddy et al., 2005 \\
\hline $\begin{array}{l}\text { Available Water Content } \\
\left(\mathrm{mm} \mathrm{H} \mathrm{H}_{2} \mathrm{O} / \mathrm{mm} \text { soil }\right)\end{array}$ & SOL_AWC & $0.17(0.13-0.19)$ & Reddy et al., 2005 \\
\hline Organic carbon $(\%)$ & $\mathrm{SOL} \_\mathrm{CBN}$ & $0.95(0.3-2.1)$ & Reddy et al., 2005 \\
\hline Soil Depth (mm) & SOL_Z & $910(120-3500)$ & Reddy et al., 2005 \\
\hline Saturated Hydraulic conductivity (mm/hr) & SOL_K & $2.0-65.0$ & $\begin{array}{l}\text { Estimated by Pedo- } \\
\text { transfer function } \\
\text { (Schaap et.al. 2001) }\end{array}$ \\
\hline Curve number (-) & $\mathrm{CN}$ & $70-80$ & $\begin{array}{l}\text { (Pathak et al, 2002; } \\
\text { Garg et al., 2011a) }\end{array}$ \\
\hline $\begin{array}{l}\text { Hydraulic conductivity of the reservoir } \\
\text { bottom }(\mathrm{mm} / \mathrm{hr})\end{array}$ & RES_K & 8.0 & Garg et al.,2011a \\
\hline Groundwater revap coeff(-) & GW_REVAP & 0.2 & Calibrated \\
\hline $\begin{array}{l}\text { Threshold depth of water for revap in } \\
\text { shallow aquifer }\left(\mathrm{mm} \mathrm{H}_{2} \mathrm{O}\right)\end{array}$ & REVAP_MN & 32 & Calibrated \\
\hline $\begin{array}{l}\text { Threshold depth of water in the shallow } \\
\text { aquifer required to return flow }\left(\mathrm{mm} \mathrm{H}_{2} \mathrm{O}\right)\end{array}$ & GWQMN & 300 & Calibrated \\
\hline Groundwater delay time (days) & GW_DELAY & 32 & Calibrated \\
\hline Channel erodibility factor(-) & CH_EROD & 0.5 & Garg et al.,2011a \\
\hline Channel cover factor (-) & CH_COV & 0.5 & Garg et al.,2011a \\
\hline USLE equation support practice factor (-) & USLE_P & 0.5 & Garg et al.,2011a \\
\hline $\begin{array}{l}\text { Peak rate adjustment factor for sediment } \\
\text { routing in the sub basin (-) }\end{array}$ & ADJ_PKR & 0.5 & Garg et al.,2011a \\
\hline $\begin{array}{l}\text { Linear parameters for calculating the } \\
\text { maximum amount of sediment that can be } \\
\text { re-entrained during channel sediment } \\
\text { routing }\end{array}$ & SPCON & 0.005 & Calibrated \\
\hline $\begin{array}{l}\text { Osman Sagar reservoir storage capacity } \\
\left(\mathrm{Mm}^{3}\right)\end{array}$ & RES_EVOL & 110.4 & HMWSSB $* *$ \\
\hline $\begin{array}{l}\text { Osman Sagar reservoir surface area at full } \\
\text { reservoir level }\left(\mathrm{km}^{2}\right)\end{array}$ & RES_ESA & 21.9 & HMWSSB \\
\hline $\begin{array}{l}\text { Total storage capacity of check dams built } \\
\text { in Osman Sagar catchment area }\left(\mathrm{Mm}^{3}\right)\end{array}$ & RES_EVOL & 0.85 & $\begin{array}{l}\text { Village census data, } \\
\text { Govt. of Andhra } \\
\text { Pradesh, India }\end{array}$ \\
\hline $\begin{array}{l}\text { Total surface area of check dams built in } \\
\text { Osman Sagar catchment area }\left(\mathrm{km}^{2}\right)\end{array}$ & RES_ESA & 0.90 & $\begin{array}{l}\text { Village census data, } \\
\text { Govt. of Andhra } \\
\text { Pradesh, India }\end{array}$ \\
\hline
\end{tabular}

*Data in parenthesis show minimum to maximum range of parameter value;

** HMWSSB: Hyderabad Metropolitan Water Supply and Sewerage Board 
Table 2b: Model validation

\begin{tabular}{llll}
\hline Parameter & Modeled value & Observed value & Source \\
\hline Osman Sagar catchment area & & & \\
$\begin{array}{l}\text { Specific Yield of the groundwater } \\
\begin{array}{l}\text { aquifer in Osman Sagar catchment } \\
\text { area }(\%)\end{array}\end{array}$ & 3.0 & 2.4 & $\begin{array}{l}\text { Massuel } \text { et al., 2007; } \\
\text { Ahmed and Sreedevi, 2008 }\end{array}$ \\
\hline
\end{tabular}

Crop yield in the Osman Sagar catchment area (data from 1999 to 2006):

\begin{tabular}{|c|c|c|c|}
\hline Average Sorghum yield (ton/ha) & 1.23 & 1.05 & $\begin{array}{l}\text { GOI, } 2010 \\
\text { (http://www.dacnet.nic.in/eands) }\end{array}$ \\
\hline Average Cotton yield (ton/ha) & 1.54 & 1.61 & GOI, 2010 \\
\hline Average Chick pea yield (ton/ha) & 0.79 & 1.04 & GOI, 2010 \\
\hline
\end{tabular}

Kothapally Watershed (data from 2001 to 2010)

Percentage of rainfall leaving (Outflow) from the watershed boundary

$8.9 \quad 10 \quad$ Observed (runoff gauge data)

Specific yield of groundwater aquifer $(\%)$

$4.3 \quad 3.1 \quad$ Garg et al.,2011a

Osman Sagar reservoir (data from 1978 to 2001)

Average annual water loss through evaporation and percolation 25 23 $\left(\mathrm{Mm}^{3}\right)$

Average annual amount of water spilled out $\left(\mathrm{Mm}^{3}\right)$

Data collected from HMWSSB,

Average annual water withdrawal for domestic purpose $\left(\mathrm{Mm}^{3}\right)$

Hyderabad, India

Water balance components of Osman Sagar catchment area: a comparison for a dry year 2004-05 (Rainfall of year 2004-05 $=595 \mathrm{~mm}$ or $440 \mathrm{Mm}^{3}$ )

Groundwater recharge in Year

2004-05 under current condition

Inflow to reservoir in year 2004-05

under current conditions

Groundwater recharge in Year 2004-05 under no mgt. condition

Inflow to reservoir in year 2004-05 under no mgt. conditions

\begin{tabular}{|c|c|}
\hline $37.5 \mathrm{Mm}^{3}$ & $32 \mathrm{Mm}^{3}$ \\
\hline $12.7 \mathrm{Mm}^{3}$ & $13.4 \mathrm{Mm}^{3}$ \\
\hline $28 \mathrm{Mm}^{3}$ & $17 \mathrm{Mm}^{3}$ \\
\hline $20 \mathrm{Mm}^{3}$ & $102 \mathrm{Mm}^{3}$ \\
\hline
\end{tabular}

EPTRI and NGRI, 2005

$\mathrm{Mm}^{3}$ : Million Cubic Meters; EPTRI: Environment Protection Training \& Research Institute; NGRI: National Geophysical Research Institute, Hyderabad, India 
Table 2c: Parameterisation of different management scenarios in comparison with current stage

\begin{tabular}{|c|c|c|c|c|c|}
\hline $\begin{array}{l}\text { Parameter values / name in } \\
\text { SWAT }\end{array}$ & Current stage & No Int. & Insitu & Exsitu & Max Int. \\
\hline \multicolumn{6}{|l|}{ In-situ interventions } \\
\hline $\begin{array}{l}\text { Insitu practices developed } \\
\left(\mathrm{km}^{2}\right)\end{array}$ & 156 & 0 & 156 & 0 & 156 \\
\hline Curve number / CNOP (-) & $\mathrm{CN}$ & $\mathrm{CN}+3$ & $\mathrm{CN}-3$ & $\mathrm{CN}+3$ & $\mathrm{CN}-3$ \\
\hline $\begin{array}{l}\text { Available water capacity / } \\
\text { AWC }\left(\mathrm{mm} \mathrm{H}_{2} \mathrm{O} / \mathrm{mm} \text { soil }\right)\end{array}$ & AWC & $0.88 \mathrm{AWC}$ & $1.12 \mathrm{AWC}^{*}$ & 0.88 AWC & $1.12 \mathrm{AWC}^{*}$ \\
\hline $\begin{array}{l}\text { Manning's roughness coef for } \\
\text { overland flow / OV_N (-) }\end{array}$ & 0.05 & 0.04 & 0.14 & 0.04 & 0.14 \\
\hline $\begin{array}{l}\text { Groundwater revap coefficient } \\
\text { / GW_REVAP (-) }\end{array}$ & $X=0.2$ & $\mathrm{X}-0.25 \mathrm{X}$ & $X+0.25 X$ & $\mathrm{X}-0.25 \mathrm{X}$ & $X+0.25 X$ \\
\hline $\begin{array}{l}\text { Threshold depth of water for } \\
\text { revap in the shallow aquifer / } \\
\text { REVAP_MN }\left(\mathrm{mm} \mathrm{H}_{2} \mathrm{O}\right) \\
\text { Threshold depth of water in the } \\
\text { shallow aquifer required to } \\
\text { return flow / GWQMN (mm } \\
\left.\mathrm{H}_{2} \mathrm{O}\right)\end{array}$ & $Z=300$ & $\mathrm{Y}+15$ & $Z^{\prime}=Z+50$ & $\mathrm{Y}+15$ & $Y^{\prime}=Y-15$ \\
\hline \multicolumn{6}{|l|}{$E x$-situ interventions } \\
\hline $\begin{array}{l}\text { Exsitu practices developed } \\
\left(\mathrm{km}^{2}\right)\end{array}$ & 552 & 0 & 0 & 552 & 552 \\
\hline $\begin{array}{l}\text { Storage capacity, ex-situ } \\
\text { management }\left(\mathrm{m}^{3} / \mathrm{ha}\right)\end{array}$ & 15 & 0 & 0 & 40 & 40 \\
\hline \multicolumn{6}{|l|}{ Crop management } \\
\hline Rainy season (Kharif) crop & Table1 & Sorghum & Cotton & Cotton & Cotton \\
\hline Post rainy (Rabi ) crop & Table1 & Chickpea & Vegetable & Vegetable & Vegetable \\
\hline Irrigated area $(\%)$ & 6.2 & 0 & 21.2 & 21.2 & 21.2 \\
\hline
\end{tabular}

*Changes are only made for the surface soil layer 
Table 3. Comparison of various land management scenarios on upstream agricultural water productivity and downstream environmental impacts in dry, normal and wet years (period from 1978 to 2008)

\begin{tabular}{|c|c|c|c|c|c|c|}
\hline Water Year & Parameters & $\begin{array}{l}\text { Current } \\
\text { state }\end{array}$ & No Int. & Insitu & Exsitu & Max Int. \\
\hline \multirow{4}{*}{$\begin{array}{l}\text { Dry years. } \\
\text { Average annual } \\
\text { rainfall: } 536 \mathrm{~mm} \\
(\sigma=33 \mathrm{~mm}) \\
\text { No of dry years: } \\
7 / 31\end{array}$} & $\begin{array}{l}\text { Groundwater recharge } \\
\left(\mathrm{Mm}^{3}\right)\end{array}$ & $\begin{array}{l}30 \\
(\sigma=12)\end{array}$ & $\begin{array}{l}27 \\
(\sigma=12)\end{array}$ & $\begin{array}{l}27 \\
(\sigma=16)\end{array}$ & $\begin{array}{l}35 \\
(\sigma=9)\end{array}$ & $\begin{array}{l}33 \\
(\sigma=15)\end{array}$ \\
\hline & $\begin{array}{l}\text { Potential irrigated area for } \\
\text { growing second crop }\left(\mathrm{km}^{2}\right)\end{array}$ & 30 & 26 & 26 & 38 & 34 \\
\hline & $\begin{array}{l}\text { Total crop production in } \\
\text { monsoon period ( } 1000 \text { tons) }\end{array}$ & & $\begin{array}{l}19.3 \\
(\sigma=6.8)\end{array}$ & $\begin{array}{l}25.6 \\
(\sigma=10.9)\end{array}$ & $\begin{array}{l}22.8 \\
(\sigma=10.6)\end{array}$ & $\begin{array}{l}25.9 \\
(\sigma=10.8)\end{array}$ \\
\hline & $\begin{array}{l}\text { Spillover releases } \\
\text { downstream to the Musi } \\
\text { river }\left(\mathrm{Mm}^{3}\right)\end{array}$ & $\begin{array}{l}1 \\
(\sigma=3)\end{array}$ & $\begin{array}{l}2 \\
(\sigma=4)\end{array}$ & $\begin{array}{l}1 \\
(\sigma=3)\end{array}$ & $\begin{array}{l}0 \\
(\sigma=0)\end{array}$ & $\begin{array}{l}0 \\
(\sigma=0)\end{array}$ \\
\hline \multirow{4}{*}{$\begin{array}{l}\text { Normal years. } \\
\text { Average annual } \\
\text { rainfall: } 733 \mathrm{~mm} \\
(\sigma=90 \mathrm{~mm}) \\
\text { No of dry years: } \\
16 / 31\end{array}$} & $\begin{array}{l}\text { Groundwater recharge } \\
\left(\mathrm{Mm}^{3}\right)\end{array}$ & $\begin{array}{l}96 \\
(\sigma=53)\end{array}$ & $\begin{array}{l}82 \\
(\sigma=47)\end{array}$ & $\begin{array}{l}83 \\
(\sigma=52)\end{array}$ & $\begin{array}{l}104 \\
(\sigma=46)\end{array}$ & $\begin{array}{l}98 \\
(\sigma=52)\end{array}$ \\
\hline & $\begin{array}{l}\text { Potential irrigated area for } \\
\text { growing second crop }\left(\mathrm{km}^{2}\right)\end{array}$ & 125 & 105 & 105 & 135 & 128 \\
\hline & $\begin{array}{l}\text { Total crop production in } \\
\text { monsoon period ( } 1000 \text { tons) }\end{array}$ & & $\begin{array}{l}21.4 \\
(\sigma=14.8)\end{array}$ & $\begin{array}{l}26.8 \\
(\sigma=6.4)\end{array}$ & $\begin{array}{l}24.5 \\
(\sigma=6.1)\end{array}$ & $\begin{array}{l}27.0 \\
(\sigma=6.2)\end{array}$ \\
\hline & $\begin{array}{l}\text { Spillover releases } \\
\text { downstream to the Musi } \\
\text { river }\left(\mathrm{Mm}^{3}\right)\end{array}$ & $\begin{array}{l}1 \\
(\sigma=4)\end{array}$ & $\begin{array}{l}11 \\
(\sigma=24)\end{array}$ & $\begin{array}{l}1 \\
(\sigma=5)\end{array}$ & $\begin{array}{l}0 \\
(\sigma=0)\end{array}$ & $\begin{array}{l}0 \\
(\sigma=0)\end{array}$ \\
\hline \multirow{4}{*}{$\begin{array}{l}\text { Wet years. } \\
\text { Average annual } \\
\text { rainfall: } 1012 \\
\text { mm } \\
(\sigma=98 \mathrm{~mm}) \\
\text { No of dry years: } \\
8 / 31\end{array}$} & $\begin{array}{l}\text { Groundwater recharge } \\
\left(\mathrm{Mm}^{3}\right)\end{array}$ & $\begin{array}{l}206 \\
(\sigma=28)\end{array}$ & $\begin{array}{l}203 \\
(\sigma=27)\end{array}$ & $\begin{array}{l}203 \\
(\sigma=29)\end{array}$ & $\begin{array}{l}234 \\
(\sigma=32)\end{array}$ & $\begin{array}{l}232 \\
(\sigma=33)\end{array}$ \\
\hline & $\begin{array}{l}\text { Potential irrigated area for } \\
\text { growing second crop }\left(\mathrm{km}^{2}\right)\end{array}$ & 295 & 287 & 287 & 333 & 329 \\
\hline & $\begin{array}{l}\text { Total crop production in } \\
\text { monsoon period ( } 1000 \text { tons) }\end{array}$ & & $\begin{array}{l}21.4 \\
(\sigma=7.8)\end{array}$ & $\begin{array}{l}27.3 \\
(\sigma=5.0)\end{array}$ & $\begin{array}{l}24.0 \\
(\sigma=5.0)\end{array}$ & $\begin{array}{l}27.9 \\
(\sigma=4.8)\end{array}$ \\
\hline & $\begin{array}{l}\text { Spillover releases } \\
\text { downstream to the Musi } \\
\text { river }\left(\mathrm{Mm}^{3}\right)\end{array}$ & $\begin{array}{l}7 \\
(\sigma=18)\end{array}$ & $\begin{array}{l}10 \\
(\sigma=22)\end{array}$ & $\begin{array}{l}5 \\
(\sigma=13)\end{array}$ & $\begin{array}{l}4 \\
(\sigma=12)\end{array}$ & $\begin{array}{l}2 \\
(\sigma=5)\end{array}$ \\
\hline
\end{tabular}


List of Figures

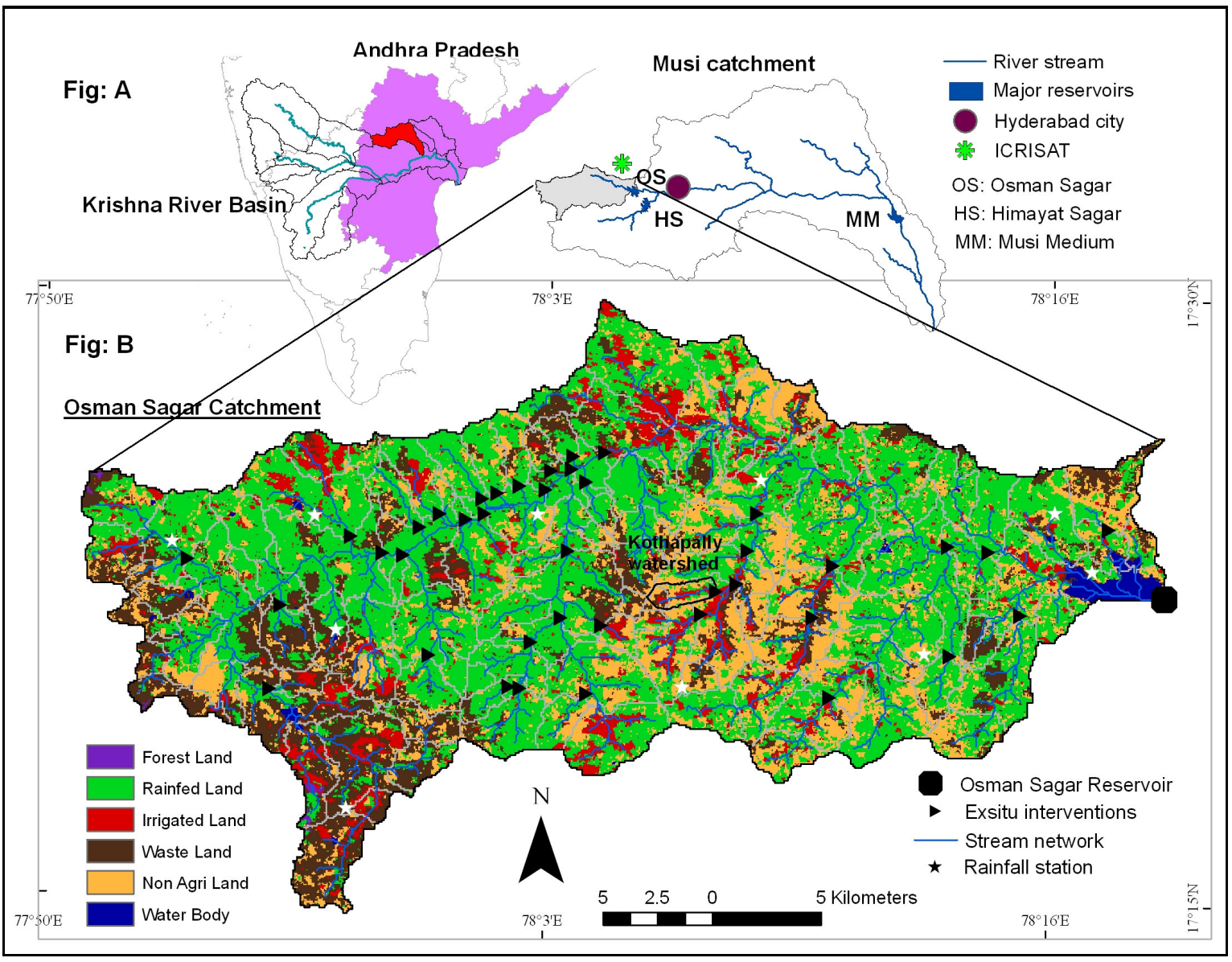

Figure 1: (A) Location of the Osman Sagar catchment in Musi sub-basin of Krishna river basin, ICRISAT and Hyderabad city, (B) Land use classification, stream network, locations of ex-situ interventions, Osman Sagar reservoir (dam), rainfall stations, and Kothapally watershed in Osman Sagar catchment area. 


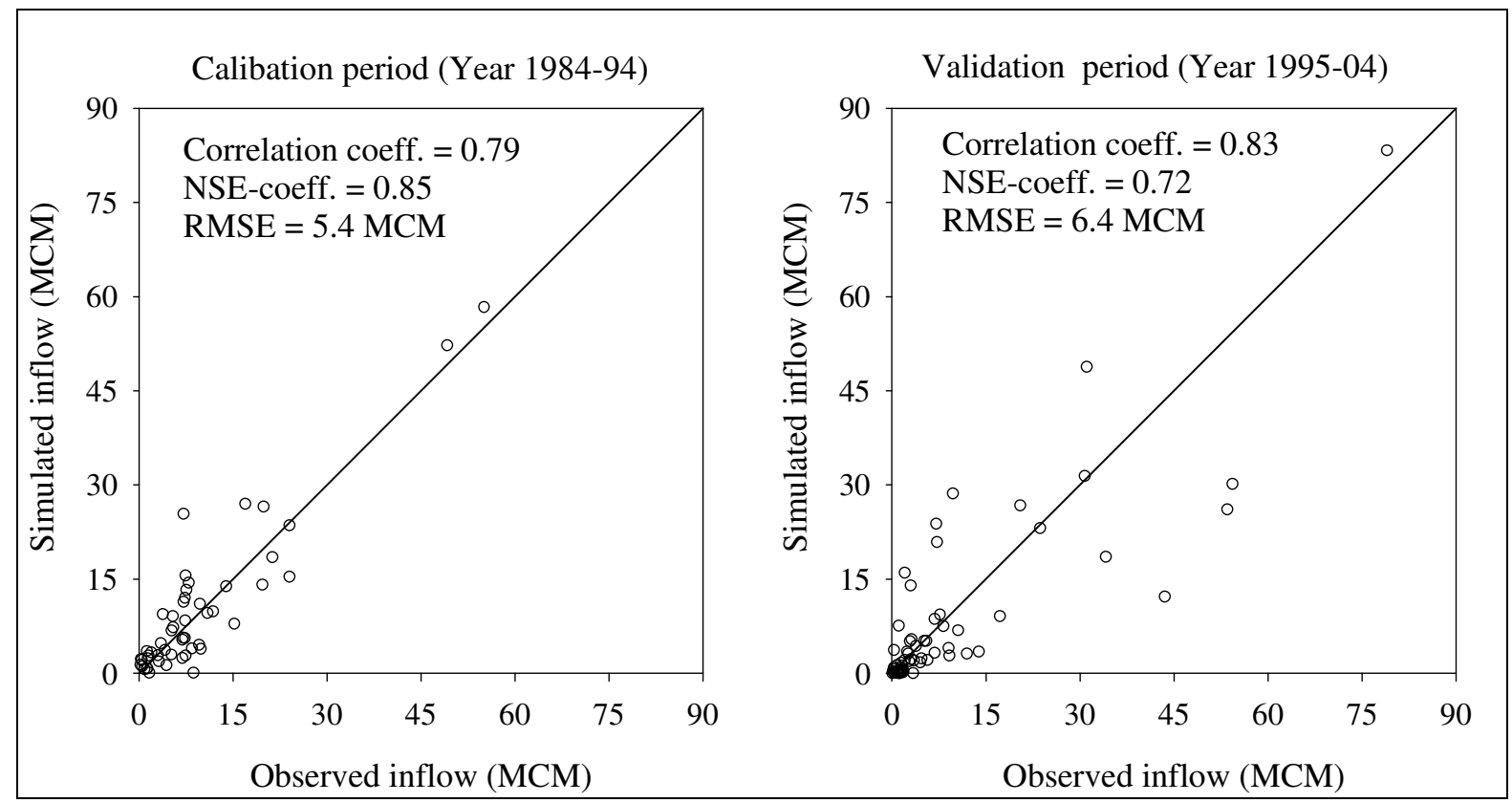

Figure 2: Observed and simulated inflow of the Osman Sagar reservoir on monthly time scale during calibration (year 1984-94) and validation period (1995-04).

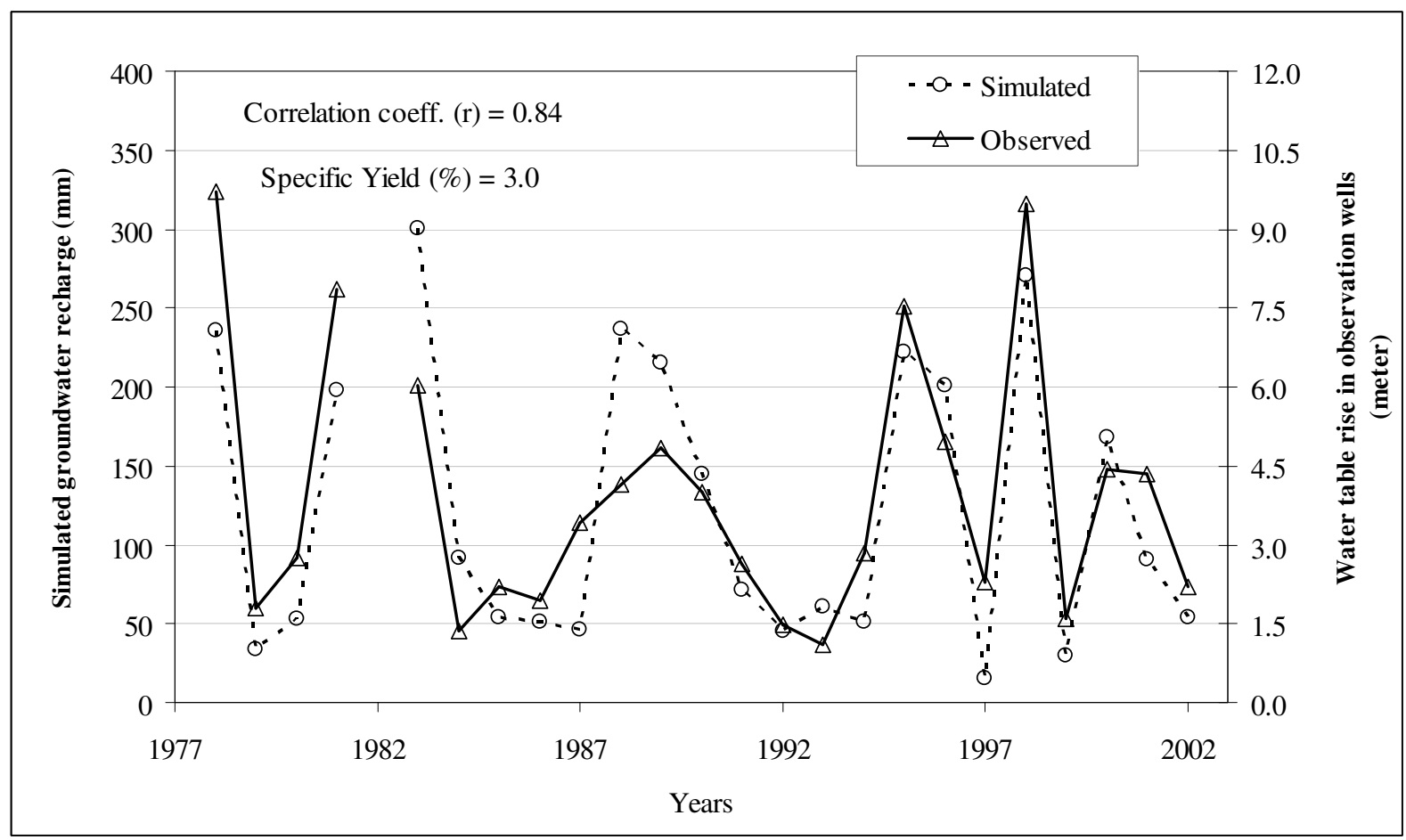

Figure 3: Correlation between simulated groundwater recharge and average increase in groundwater table after the monsoon season in observation wells between year 1978 and 2002. 


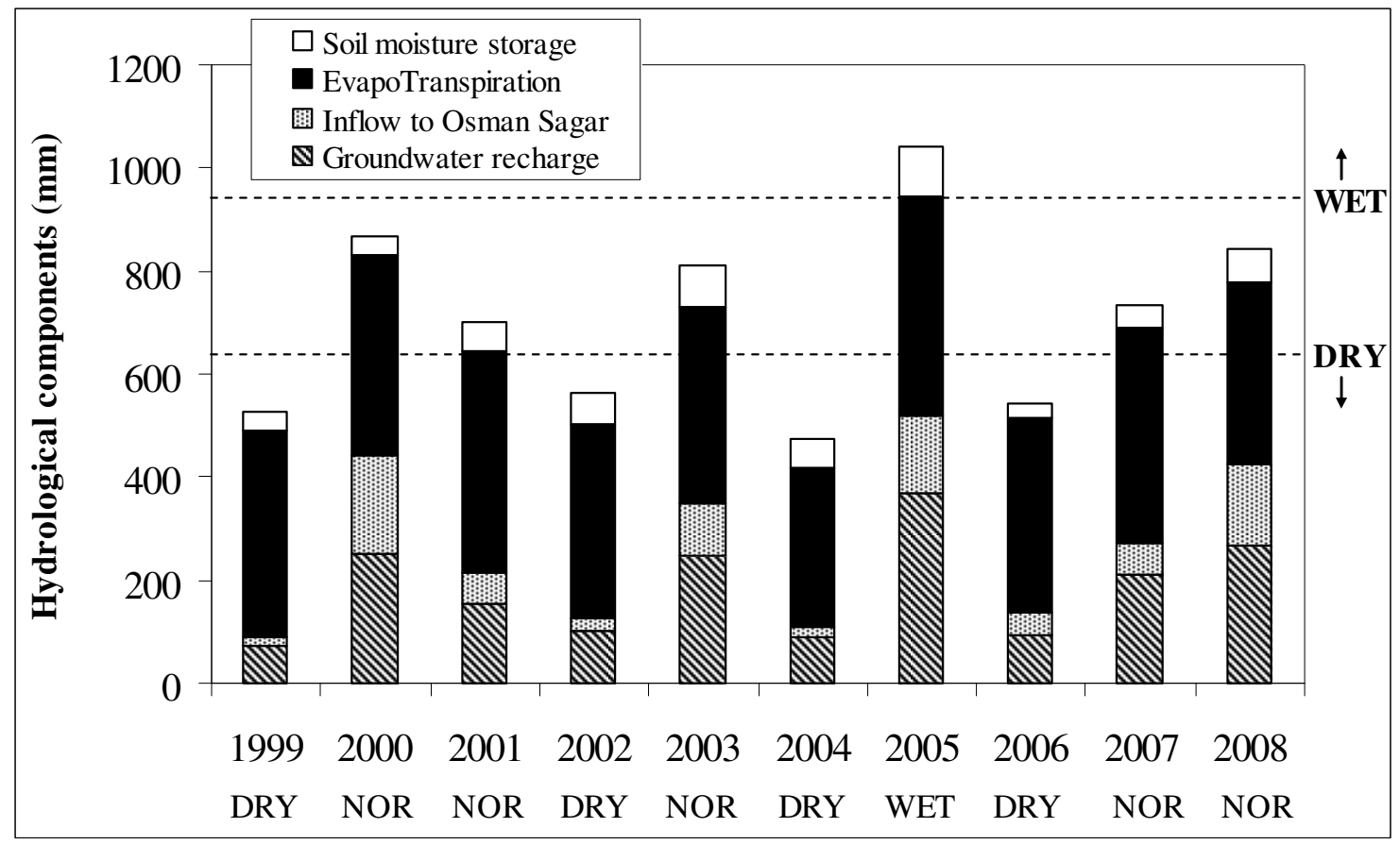

Figure 4: Monsoonal water balance of the Osman Sagar catchment area under current conditions (data from 1999 to 2008)

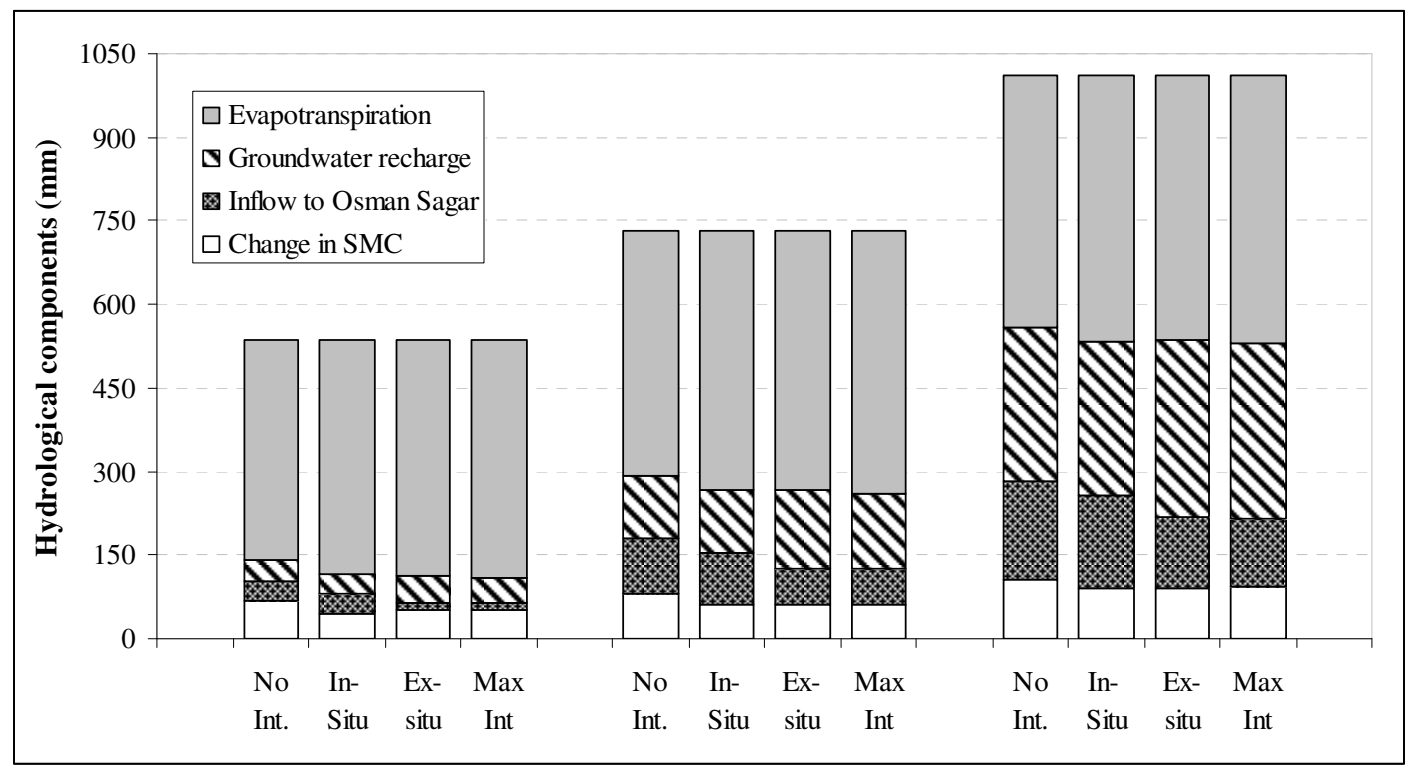

Figure 5: Water balance of the Osman Sagar catchment area under four water management scenarios in dry, normal and wet years (data from 1978 to 2008) 


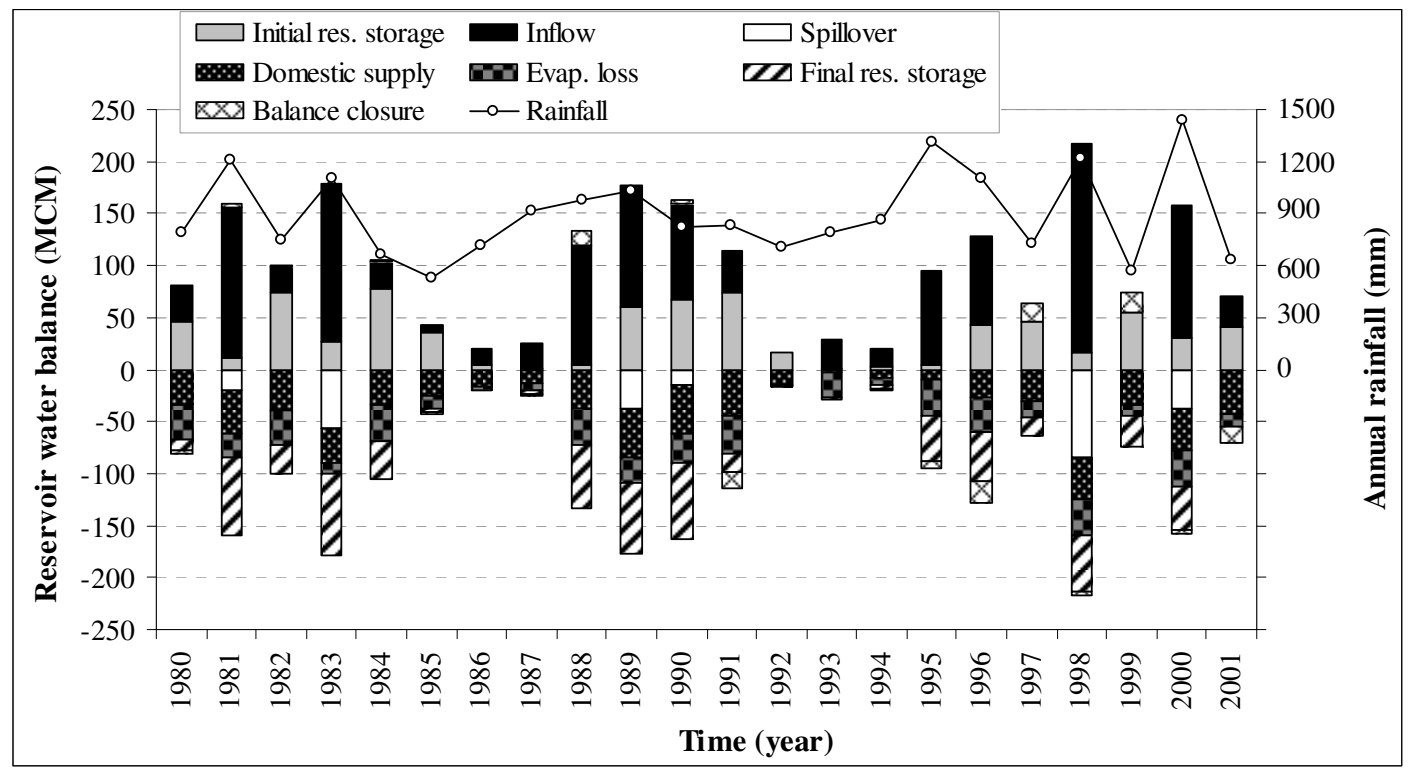

Figure 6: Water balance of the Osman Sagar reservoir under current conditions (observed data from year 1980 to 2001). The reservoir water balance is described according to the following mass balance equation: Reservoir storage at the beginning of monsoon+ Inflow at Osman Sagar reservoir $=$ Reservoir storage at the end of the monsoon + Spill over releases + Domestic water supply + Evaporation/Percolation losses + Balance closure. The balance closure term is an unaccounted water amount.

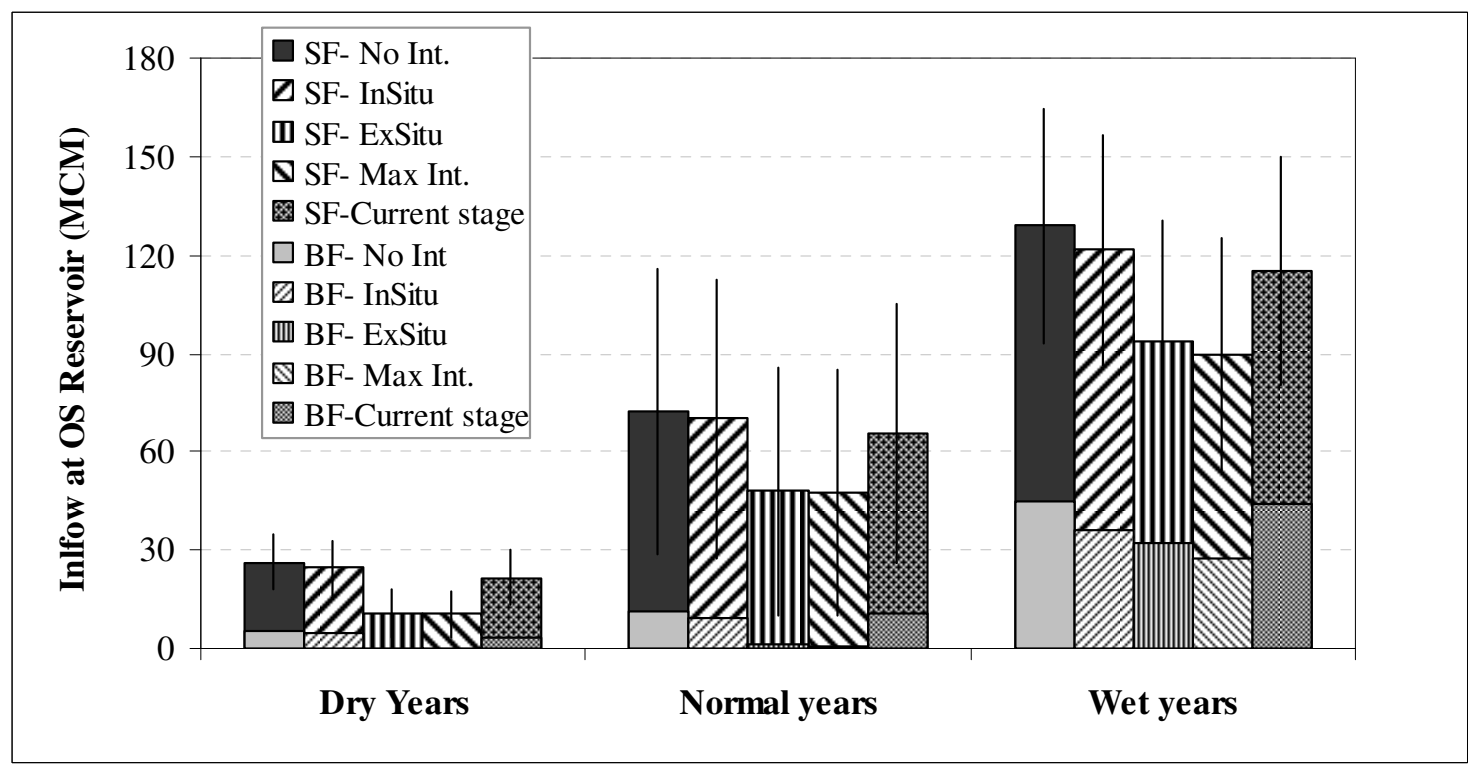

Figure 7: Inflow to the Osman Sagar reservoir under four water management and current stage scenarios in dry, normal and wet years (data from 1978 to 2008), Total inflow is divided into storm flow (SF) shown at upper part of staple and base flow (BF) shown at lower part of staple. Error bars show standard deviation 


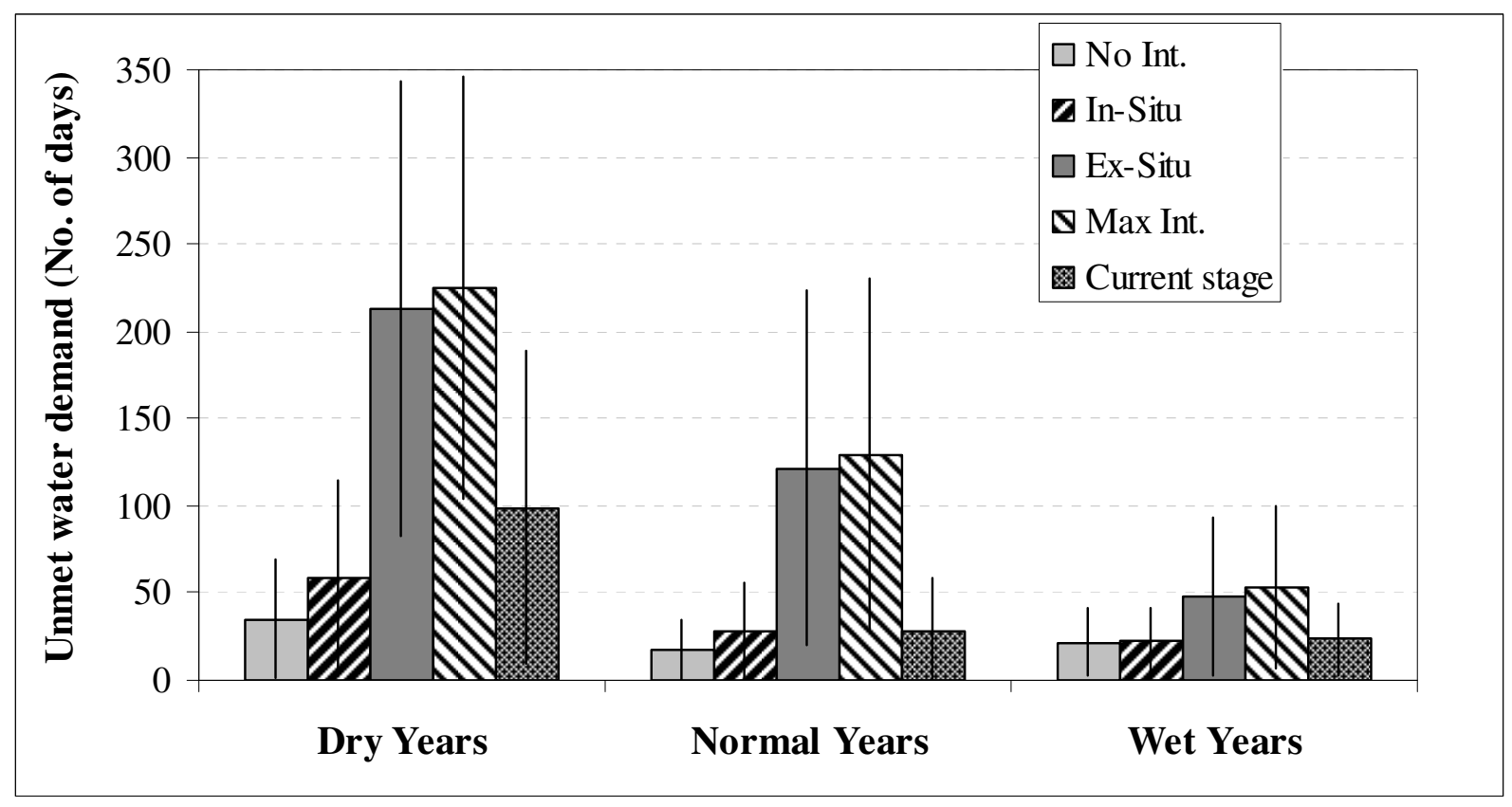

Figure 8: Unmet domestic water demand under various water intervention scenarios in dry, normal and wet years (data from 1978 to 2008); Error bars show standard deviation

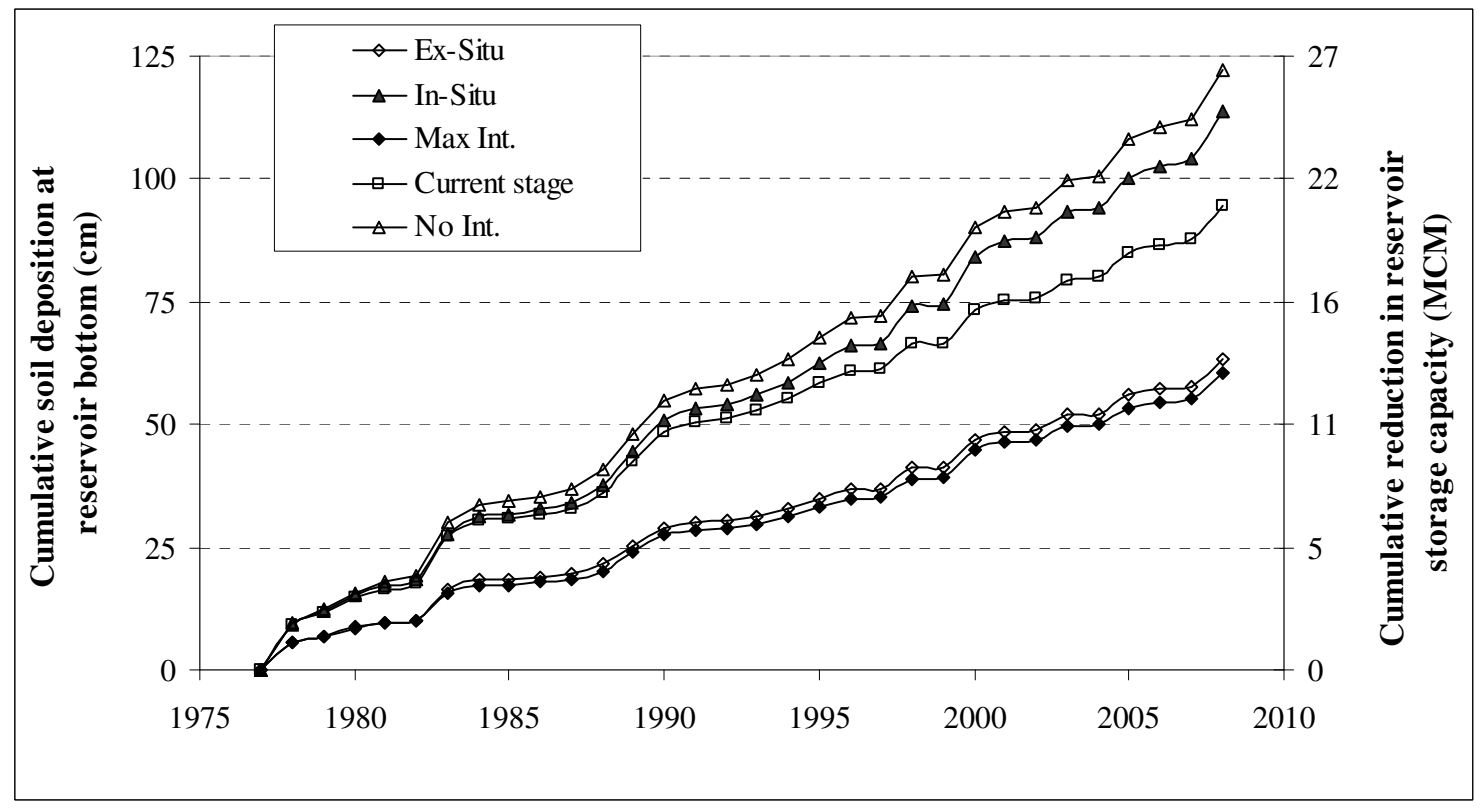

Figure 9: Sediment deposition at the reservoir bed (left y-axis) and the corresponding reduction in reservoir storage capacity (right y-axis), under four water intervention scenarios and the current situation (data from 1978 to 2008). 


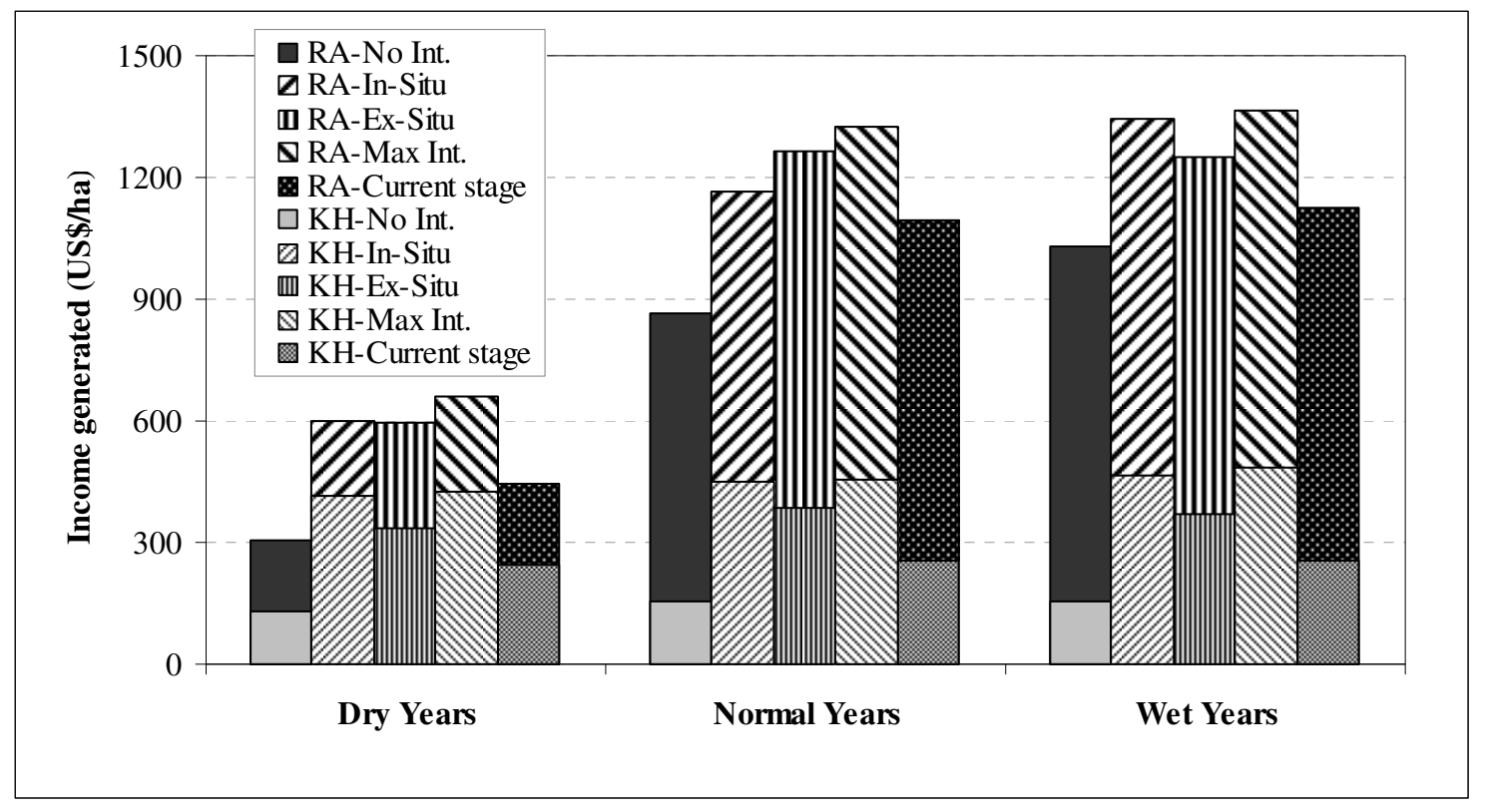

Figure 10: Farm net incomes under various water intervention scenarios during dry, normal and wet years (data from 1978 to 2008). Incomes from the Kharif season (KH) shown at lower part of staples, incomes form the Rabi season (RA) shown at upper part of staples. 


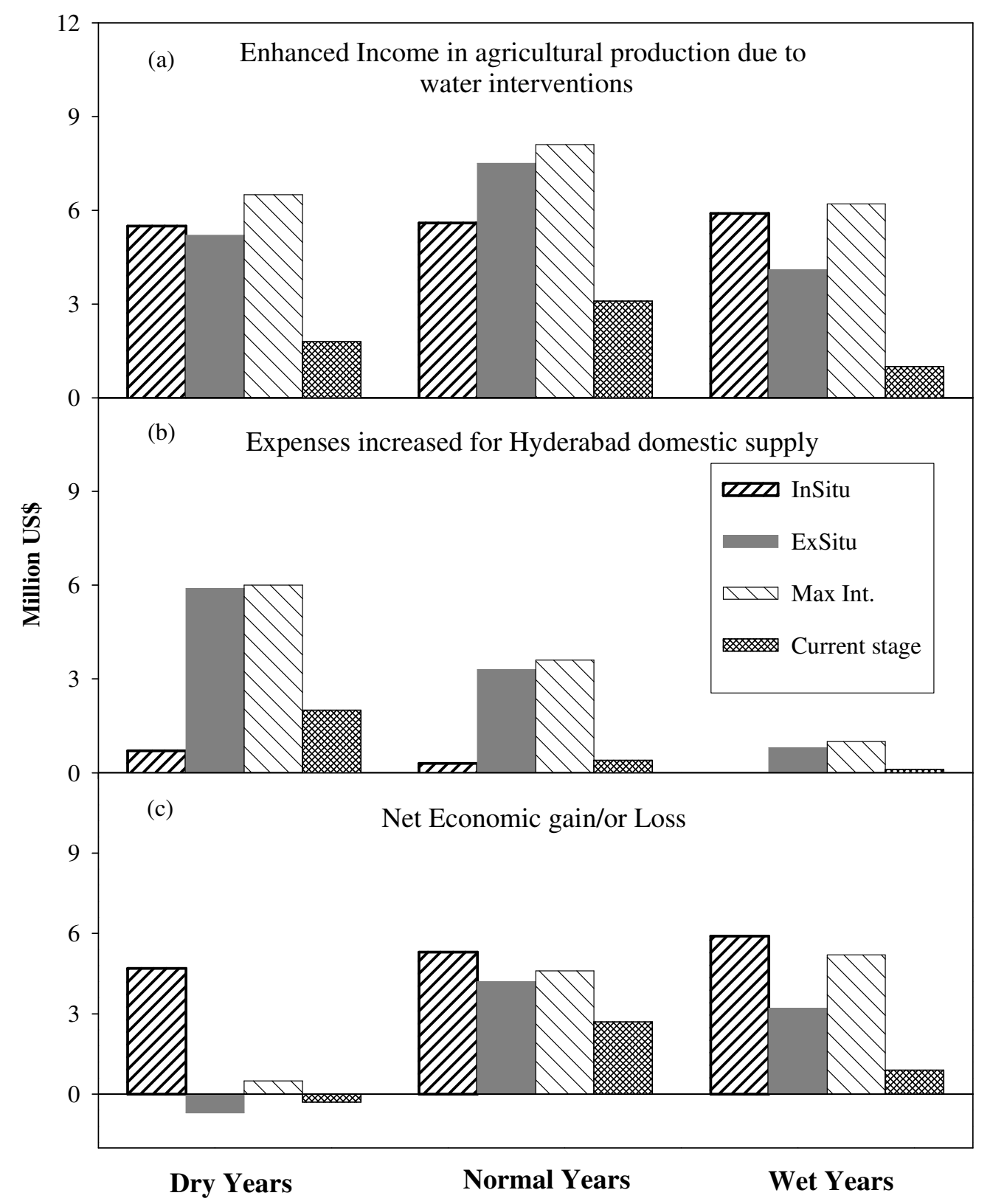

Figure 11: Trade-offs analysis of a) enhanced agricultural incomes, b) increased costs for domestic water supply to Hyderabad, and c) net economic returns/losses, for three water interventions and base line scenarios compared to no interventions, under dry, normal and wet years 